\title{
Modelling climate change responses in tropical forests: similar productivity estimates across five models, but different mechanisms and responses
}

\author{
L. Rowland ${ }^{1}$, A. Harper ${ }^{2}$, B. O. Christoffersen ${ }^{1,3}$, D. R. Galbraith ${ }^{4}$, H. M. A. Imbuzeiro ${ }^{5}$, T. L. Powell ${ }^{6}$, C. Doughty ${ }^{7}$, \\ N. M. Levine ${ }^{8}$, Y. Malhi ${ }^{7}$, S. R. Saleska ${ }^{3}$, P. R. Moorcroft ${ }^{6}$, P. Meir ${ }^{1,9}$, and M. Williams ${ }^{1}$ \\ ${ }^{1}$ School of GeoSciences, University of Edinburgh, Edinburgh, UK \\ ${ }^{2}$ College of Engineering, Mathematics, and Physical Science, University of Exeter, Exeter, UK \\ ${ }^{3}$ Department of Ecology and Evolutionary Biology, University of Arizona, Tucson, Arizona, USA \\ ${ }^{4}$ School of Geography, University of Leeds, Leeds, UK \\ ${ }^{5}$ Grupo de Pesquisas em Interação Atmosfera-Biosfera, Universidade Federal de Viçosa, Minas Gerias, Brazil \\ ${ }^{6}$ Department of Organismic and Evolutionary Biology, Harvard University, Cambridge, Massachusetts, USA \\ ${ }^{7}$ Environmental Change Institute, School of Geography and the Environment, University of Oxford, Oxford, UK \\ ${ }^{8}$ Department of Biological Sciences, University of Southern California, Los Angeles, CA, USA \\ ${ }^{9}$ Research School of Biology, Australian National University, Canberra, ACT 2601, Australia
}

Correspondence to: L. Rowland (lucy.rowland@ed.ac.uk)

Received: 17 October 2014 - Published in Geosci. Model Dev. Discuss.: 19 November 2014

Revised: 16 February 2015 - Accepted: 27 March 2015 - Published: 21 April 2015

\begin{abstract}
Accurately predicting the response of Amazonia to climate change is important for predicting climate change across the globe. Changes in multiple climatic factors simultaneously result in complex non-linear ecosystem responses, which are difficult to predict using vegetation models. Using leaf- and canopy-scale observations, this study evaluated the capability of five vegetation models (Community Land Model version 3.5 coupled to the Dynamic Global Vegetation model - CLM3.5-DGVM; Ecosystem Demography model version 2 - ED2; the Joint UK Land Environment Simulator version 2.1 - JULES; Simple Biosphere model version 3 $\mathrm{SiB} 3$; and the soil-plant-atmosphere model - SPA) to simulate the responses of leaf- and canopy-scale productivity to changes in temperature and drought in an Amazonian forest.

The models did not agree as to whether gross primary productivity (GPP) was more sensitive to changes in temperature or precipitation, but all the models were consistent with the prediction that GPP would be higher if tropical forests were $5^{\circ} \mathrm{C}$ cooler than current ambient temperatures. There was greater model-data consistency in the response of net ecosystem exchange (NEE) to changes in temperature than in the response to temperature by net photosynthesis $\left(A_{\mathrm{n}}\right)$,
\end{abstract}

stomatal conductance $\left(g_{\mathrm{s}}\right)$ and leaf area index (LAI). Modelled canopy-scale fluxes are calculated by scaling leaf-scale fluxes using LAI. At the leaf-scale, the models did not agree on the temperature or magnitude of the optimum points of $A_{\mathrm{n}}, V_{\mathrm{cmax}}$ or $g_{\mathrm{s}}$, and model variation in these parameters was compensated for by variations in the absolute magnitude of simulated LAI and how it altered with temperature.

Across the models, there was, however, consistency in two leaf-scale responses: (1) change in $A_{\mathrm{n}}$ with temperature was more closely linked to stomatal behaviour than biochemical processes; and (2) intrinsic water use efficiency (IWUE) increased with temperature, especially when combined with drought. These results suggest that even up to fairly extreme temperature increases from ambient levels $\left(+6^{\circ} \mathrm{C}\right)$, simulated photosynthesis becomes increasingly sensitive to $g_{\mathrm{s}}$ and remains less sensitive to biochemical changes. To improve the reliability of simulations of the response of Amazonian rainforest to climate change, the mechanistic underpinnings of vegetation models need to be validated at both leaf- and canopy-scales to improve accuracy and consistency in the quantification of processes within and across an ecosystem. 


\section{Introduction}

Continuing increases in atmospheric $\mathrm{CO}_{2}$ are likely to cause increases in temperature and changes in precipitation across Amazonia (Good et al., 2013; Jupp et al., 2010; Malhi et al., 2009; Marengo et al., 2012). However, significant uncertainty remains regarding the response of tropical forests to warming (Corlett, 2011; Reed et al., 2012; Wood et al., 2012), altered precipitation (Meir et al., 2008; Meir and Woodward, 2010) and short-term abrupt changes in both precipitation and temperature (Cox et al., 2008; Marengo et al., 2011; Reichstein et al., 2013). Such uncertainties are propagated into models, resulting in substantial variability in modelled responses to changes in temperature and drought (Friedlingstein et al., 2006; Galbraith et al., 2010; Powell et al., 2013; Sitch et al., 2008). These responses need to be rigorously assessed to enable further improvement in our ability to predict the impacts of climate change on rain forest functioning.

The ecosystem responses of models to multi-factor changes in climate can be difficult to interpret because of complex non-linear responses (Zhou et al., 2008), which can vary substantially between vegetation models with different model structures. Previous modelling analyses have shown a greater sensitivity of carbon storage in Amazonian forests to increased temperature than reduced precipitation (Galbraith et al., 2010). However, model responses to simultaneous changes in precipitation and temperature complex are difficult to evaluate due to the compound effect of drought and temperature responses (Luo et al., 2008). There are particular challenges when considering short-to-medium-term responses (Luo et al., 2008) linked to climatic extremes, such as severe drought (Cox et al., 2008; Marengo et al., 2011).

Concurrent changes in temperature and precipitation can cause a complex chain of positive and negative feedbacks on different timescales (Fig. 1). Increased temperature and reduced precipitation can directly affect stomatal conductance $\left(g_{\mathrm{s}}\right)$ through increasing vapour pressure deficit (VPD), or indirectly affect $g_{\mathrm{s}}$ on longer timescales through reducing soil water content (SWC; Fig. 1). Stomatal conductance, $g_{\mathrm{s}}$, limits photosynthesis $\left(A_{\mathrm{n}}\right)$, and therefore gross primary productivity (GPP). However, $A_{\mathrm{n}}$ can also be limited by changes in leaf biochemistry ( $V_{\text {cmax }}$ and $J_{\max }$; Fig. 1 ). How $A_{\mathrm{n}}$ is limited by temperature increase is important as changes in leaf biochemistry at very high temperatures can result from permanent alteration and possible damage to proteins, whereas changes in $g_{\mathrm{s}}$ are less permanent, but alter water use, and potentially water use efficiency. Currently, there is no consensus on how $A_{\mathrm{n}}$ will respond to temperature: some studies find a direct impact through leaf biochemistry (Doughty, 2011; Doughty and Goulden, 2008), and others an indirect effect initiated by changes in $g_{\mathrm{s}}$, because the limitation of increasing VPD on $g_{\mathrm{s}}$ occurs at lower temperatures than those that cause protein damage (Lloyd and Farquhar, 2008). The lack of data for tropical trees means these responses remain

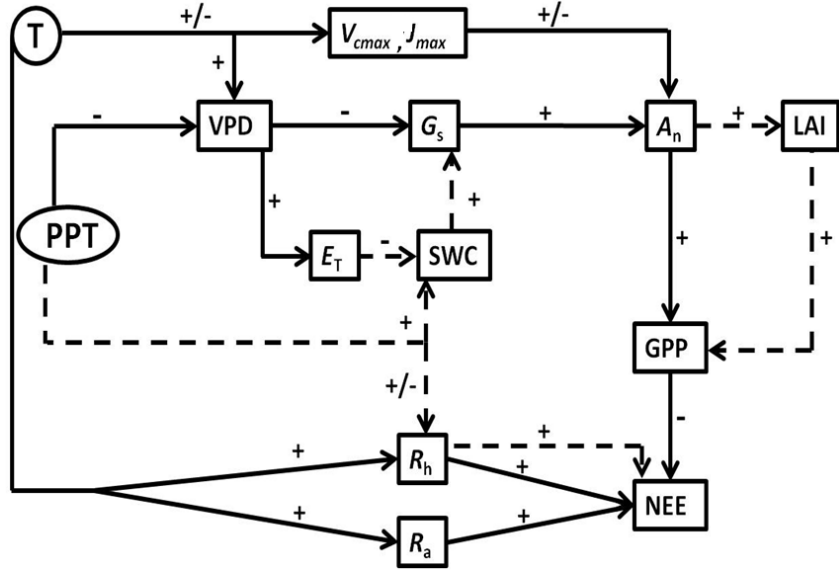

Figure 1. Schematic diagram showing how droughts, via the combined effects of increased air temperature $(T)$ and reduced precipitation (PPT), affect the carbon cycle of a tropical forest, including the effects on vapour pressure deficit (VPD), evapo-transpiration $\left(E_{\mathrm{t}}\right)$, stomatal conductance $\left(g_{\mathrm{S}}\right)$, soil water content (SWC), net photosynthesis $\left(A_{\mathrm{n}}\right)$, leaf area index (LAI), the maximum rates of RuBP carboxylation and electron transport ( $V_{\mathrm{cmax}}$ and $J_{\max }$, respectively), autotrophic respiration $\left(R_{\mathrm{a}}\right)$ heterotrophic respiration $\left(R_{\mathrm{h}}\right)$, gross primary productivity (GPP), and net ecosystem exchange (NEE); + signs indicate a positive feedback effect between variables (i.e. an increase in one variable can only cause an increase in another if all else is equal), - signs indicate a negative feedback effect, and +/indicate the possibility of both a positive and negative effect. Solid arrows represent responses which occur over short timescales of minutes to hours, whereas dashes arrows represent responses which can occur over longer timescales from days to months.

poorly constrained, though drought and warming can be examined using limited field data from drought and warming experiments (da Costa et al., 2014, 2010; Nepstad et al., 2002) and from extreme events within the natural range of the climate (Marengo et al., 2011).

The response of vegetation models to temperature change or drought occurs through the aggregated changes in finerscale processes, for example at the leaf level. Correctly simulating the mechanisms at the leaf scale is therefore important to maintain confidence in canopy-scale predictions. Leaf-scale responses in models are scaled using leaf area index (LAI) to simulate the processes at the canopy-scale; therefore, inaccuracies in both leaf-scale fluxes and how they are scaled can produce substantial errors in ecosystem-scale fluxes (Bonan et al., 2012). Currently, no model-data comparisons exist that allow for the evaluation of combined temperature and precipitation/drought sensitivity of ecosystem fluxes in relation to LAI and leaf-scale processes in tropical forests. However, if we are to identify accurately how to improve simulated responses of Amazonian forests to future climate change, it is vital that model output is evaluated against data from the leaf to the canopy scale. 
At the Tapajós National Forest (TNF) in north-east Brazil, Doughty and Goulden (2008) collected data on the response of net ecosystem exchange (NEE) to change in atmospheric temperature and the response of $A_{\mathrm{n}}$ and $g_{\mathrm{s}}$ to short-term artificial leaf warming. Doughty and Goulden (2008) found reductions in forest productivity at air temperatures above $28^{\circ} \mathrm{C}$, which corresponds to significant reductions in $A_{\mathrm{n}}$ and $g_{\mathrm{s}}$ at leaf temperatures above $30-33^{\circ} \mathrm{C}$. They suggested that tropical forests may therefore already be close to a temperature threshold, beyond which productivity will decline.

Here we use the data published by Doughty and Goulden (2008) to evaluate the short-term temperature responses within models at both the leaf and canopy-scale and investigate how the model formulations might impact predicted responses to multiple climatic factors. Our model simulations represent short-term non-equilibrium responses to changes in temperature to make them comparable to the perturbation data collected by Doughty and Goulden (2008). Evaluation of non-equilibrium changes in models is valuable for assessing how models will perform when simulating responses to extreme shifts in temperature and precipitation which are predicted to increase across Amazonia (Cox et al., 2008; Marengo et al., 2011). If the models run their equilibrium response to a simulated climate shift, the changes in some of the key variables in the study $\left(A_{\mathrm{n}}, g_{\mathrm{s}}\right)$ are more likely to be dominated by the effect of long-term soil drying rather than direct temperature responses (e.g. the dashed lines in Fig. 1). This study is part of a wider model inter-comparison project which aims to explore how well vegetation models simulate drought in the eastern Amazon (Powell et al., 2013). In this study we evaluate (1) how the forest productivity of five vegetation models (Community Land Model version 3.5 coupled to the Dynamic Global Vegetation model CLM3.5-DGVM (hereafter CLM3.5); Ecosystem Demography model version 2 - ED2; the Joint UK Land Environment Simulator version 2.1 - JULES; Simple Biosphere model version 3 - SiB3; and the soil-plant-atmosphere model SPA) responds to changes in temperature, (2) what leafscale processes drive canopy-scale changes in productivity and (3) how both leaf- and canopy-scale temperature sensitivities are influenced by concurrent changes in precipitation at the Tapajós forest site in eastern Brazil. In all models we simulate first an ambient and then a $50 \%$ reduction in the incoming precipitation during the wet season from 2000 to 2006 analogous to the drought treatment imposed at the Tapajós forest site, linked to a $-5,0,+2,+4$, and $+6{ }^{\circ} \mathrm{C}$ change to the ambient air temperature $\left(T_{\text {air }}\right)$. These simulations cover a range of likely and possible increases in temperature for the Amazon region in the coming century (Christensen et al., 2007; Collins et al., 2013; Malhi et al., 2009) and can be evaluated against existing data from Doughty and Goulden (2008). This study is the first to evaluate, using data, the inter-model variability in the leaf and canopy responses to changes in temperature and precipitation at a tropical forest site.

\section{Materials and methods}

\subsection{Model description}

The five models used in this study are the CLM3.5, the ED2, JULES, SiB3, and the SPA. A brief description of each of the models is given here and in Table 1 (also see Powell et al., 2013). The simplest canopy structure is in SiB3. SiB3 has a fixed LAI and uses a big-leaf model which simulates the response of the top canopy and integrates this response throughout the canopy according to a light and leaf nitrogen $(\mathrm{N})$ extinction coefficient (Baker et al., 2008; Sellers et al., 1992, 1996). CLM3.5 is also a big-leaf model; however, it separates the canopy into a sunlit leaf fraction (leaves which receive both direct and diffuse light) and a shaded leaf fraction (leaves which receive only diffuse light), which change dynamically with sun angle and canopy light penetration (Oleson et al., 2004, 2008). The version of JULES used in this study simulates 10 canopy layers with equal leaf area increments. Leaf nitrogen decays exponentially through the canopy and radiation interception is simulated following the two-stream approximation of Sellers (1985). SPA also has a layered canopy model, and here used three canopy layers, with separate sunlit and shaded fractions (Williams, 1996; Williams et al., 2005). ED2 mathematically approximates the properties of an individual-based forest gap model, separately modelling the stems of three successional stages (pioneer, mid-successional and late successional) of, in this study, tropical trees and grasses on a continuum of leaf light levels from fully shaded to fully sunlit (Kim et al., 2012; Medvigy et al., 2009b; Moorcroft et al., 2001). SiB3 and SPA simulate only one plant functional type (PFT), set to tropical evergreen broadleaf; JULES and CLM3.5 simulate five PFT's, but this site simulated a fractional cover $>95 \%$ evergreen broadleaf trees. As the focus of this study is the responses within tropical forests, results were not considered if a model simulated a shift in the PFT away from the dominance of tropical forest.

All of the models use enzyme-kinetic $A_{\mathrm{n}}$ equations, derived from Farquhar et al. (1980), Farquhar and Sharkey (1982), Kirschbaum and Farquhar (1984) and Collatz et al. (1991). In all models, temperature can affect $A_{\mathrm{n}}$ directly through temperature response functions on the maximum rate of carboxylation of $\operatorname{RuBP}\left(V_{\mathrm{cmax}}\right)$, the $\mathrm{CO}_{2}$ compensation point, and the Michaelis-Menten constants $\left(K_{\mathrm{c}}\right.$ and $\left.K_{\mathrm{o}}\right)$ and in SPA the maximum rate of electron transport $\left(J_{\max }\right)$. Temperature can also indirectly change $A_{\mathrm{n}}$ through changing the VPD at the leaf surface, which alters $g_{\mathrm{s}}$. CLM3.5, ED2 and SiB3 use the Ball-Berry stomatal conductance model (Collatz et al., 1991). JULES calculates $g_{\mathrm{S}}$ by relating the ratio of internal to external $\mathrm{CO}_{2}$ to the humidity deficit (Cox et al., 1998). SPA is unique in that it models stomatal conductance by simulating an aqueous continuum between the soil and leaf water: $g_{\mathrm{s}}$ and photosynthesis are maximised using an isohydric assumption that at each time 
Table 1. Summary of the characteristics of each of the five vegetation models (CLM3.5, ED2, JULES, SiB3, and SPA).

\begin{tabular}{|c|c|c|c|c|c|}
\hline & CLM3.5 & ED2 & JULES & SiB3 & SPA \\
\hline $\begin{array}{l}\text { No. of plant function } \\
\text { types }\end{array}$ & 5 & 4 & 10 & 1 & 1 \\
\hline Canopy structure & Big leaf & Gap model & Layered canopy & Big leaf & Layered canopy \\
\hline Leaf area index & Dynamic & Dynamic & Dynamic & Fixed & Dynamic \\
\hline $\begin{array}{l}\text { Division of sunlit and } \\
\text { shaded leaf }\end{array}$ & $\mathrm{Y}$ (discrete division) & $\mathrm{N}$ & $\mathrm{N}$ & $\mathrm{N}$ & $\mathrm{Y}$ (discrete division) \\
\hline $\begin{array}{l}\text { Simulation of water stress } \\
\text { on } A_{\mathrm{n}} \text { and } g_{\mathrm{s}} \text {. }\end{array}$ & Water stress factor & Water stress factor & Water stress factor & Water stress factor & $\begin{array}{l}\text { Linked soil-leaf water po- } \\
\text { tential/resistance model to } \\
g_{\mathrm{s}} \text { model. }\end{array}$ \\
\hline $\begin{array}{l}\text { Origin of photosynthesis } \\
\text { model }\end{array}$ & $\begin{array}{l}\text { Farquhar et al. (1980), } \\
\text { Farquhar and Sharkey } \\
(1982), \\
\text { Collatz et al. (1991) }\end{array}$ & $\begin{array}{l}\text { Farquhar et al. (1980), } \\
\text { Farquhar and Sharkey } \\
(1982) \text {, } \\
\text { Collatz et al. (1991) }\end{array}$ & $\begin{array}{l}\text { Farquhar et al. (1980), } \\
\text { Farquhar and Sharkey } \\
(1982) \text {, } \\
\text { Collatz et al. (1991) }\end{array}$ & $\begin{array}{l}\text { Farquhar et al. (1980), } \\
\text { Farquhar and Sharkey } \\
\text { (1982), } \\
\text { Collatz et al. (1991) }\end{array}$ & $\begin{array}{l}\text { Farquhar et al. (1980), } \\
\text { Kirschbaum and Farquhar } \\
\text { (1984), } \\
\text { McMurtrie et al. (1992) }\end{array}$ \\
\hline Key model references & $\begin{array}{l}\text { Bonan et al. (2003), } \\
\text { Levis et al. (2004), } \\
\text { Oleson et al. (2008) }\end{array}$ & $\begin{array}{l}\text { Medvigy et al. (2009), } \\
\text { Kim et al. (2012) }\end{array}$ & $\begin{array}{l}\text { Best et al. (2011), } \\
\text { Clark et al. (2011) }\end{array}$ & $\begin{array}{l}\text { Sellers et al. (1992), } \\
\text { Sellers et al. (1996), } \\
\text { Baker et al. (2008) }\end{array}$ & $\begin{array}{l}\text { Williams (1996), } \\
\text { Williams et al. (2005), } \\
\text { Fisher et al. (2006) }\end{array}$ \\
\hline
\end{tabular}

step leaf water potential does not drop below a critical level ( $-2.5 \mathrm{MPa}$; see Williams et al., 1996; Fisher et al., 2007). CLM3.5, ED2, SiB3 and JULES alter $g_{\mathrm{s}}$ using a water stress factor ( $\beta$; a value ranging $0-1$ where 1 indicates no soil water stress and 0 indicates complete soil water limitation). A detailed description of the effect of soil water stress on $g_{\mathrm{s}}$ and $A_{\mathrm{n}}$ in these models is given by Powell et al. (2013).

\subsection{Site}

The throughfall exclusion in the TNF $\left(2.897^{\circ} \mathrm{S}, 54.952^{\circ} \mathrm{W}\right)$ is located on an Oxisol soil, and has a mean annual precipitation of approximately $2 \mathrm{~m}$ per year; the site is described in detail by Nepstad et al. (2002). This plot was selected for this experiment because the temperature response of canopylevel NEE was collected at a nearby site (km83; Doughty and Goulden, 2008). The canopy NEE measurements were from an eddy covariance tower from July 2000 to July 2001, when light levels were above $1000 \mu \mathrm{mol} \mathrm{m}^{-2} \mathrm{~s}^{-1}$ (Doughty and Goulden, 2008). Leaf-level responses of stomata conductance and photosynthesis to increases in leaf temperature in fully sunlit canopy leaves were from three species in 2004 (see Doughty and Goulden, 2008 and Goulden et al., 2004).

\subsection{Meteorological data and soil properties}

The model simulations were driven using hourly meteorological data (precipitation, $T_{\text {air }}$, specific humidity, short and long-wave radiation and air pressure) measured above the canopy at the site from 1 January 2002 to 31 December 2004. The short-wave radiation was split into $68 \%$ direct and $32 \%$ diffuse, and then this was split into $43 \%$ visible and $57 \%$ near-infrared for direct, and $52 \%$ visible and $48 \%$ nearinfrared for diffuse (Goudriaan, 1977).

The soil properties were standardised across all models to create a similar soil physical environment, thereby testing only for differences in vegetation functioning (see Powell et al., 2013). Only biological properties such as rooting depth, root biomass, as well as the total number of soil layers were left as model specific soil properties.

\subsection{Experimental design}

All of the models went through a standard spin-up procedure prior to simulations (see Powell et al., 2013). Following the spin-up period, a series of five model simulations, with varying $T_{\text {air }}$, were performed for an 8-year period (which was intended to simulate 1999-2006; see Powell et al., 2013) for ambient precipitation (control simulations) and for simulations with a $50 \%$ reduction in wet season rainfall (drought simulations). The 2002-2004 meteorological data were recycled over the 8-year simulation period. To explore the effects of changes in $T_{\text {air }}$ on the models, we performed five model simulations which consisted of simulations with the hourly 2000-2006 ambient $T_{\text {air }}$ adjusted by $-5,0^{\circ} \mathrm{C}$ (ambient $T_{\text {air }}$ ), $+2,+4$ and $+6^{\circ} \mathrm{C} ; 1999$ was the baseline year for which no changes from ambient temperature and precipitation were implemented. Our analysis was focused on increases in temperature; however, we included a simulation with temperatures $5{ }^{\circ} \mathrm{C}$ lower than ambient temperatures, on the basis that some models may have processes optimised for temperate regions where average $T_{\text {air }}$ is lower. VPD was adjusted according to the changes in air temperature.

\subsection{Model output and evaluation}

All the data in this study was processed to match the collection methods and processing done by Doughty and Goulden (2008; hereafter referred to as DG), as closely as possible. Therefore, to compare the models' predictions NEE with the flux data, we extracted canopy-level fluxes when photosynthetic photon flux density (PPFD) was $>1000 \mu \mathrm{mol} \mathrm{m}^{-2} \mathrm{~s}^{-1}$, the conditions used by DG. PPFD was not available for the whole period; therefore, we used the measured short-wave radiation to estimate PPFD. A conversion factor of 2 is used to convert from short-wave radiation $\left(\mathrm{W} \mathrm{m}^{-2}\right)$ to PPFD $\left(\mu \mathrm{mol} \mathrm{m} \mathrm{m}^{-2} \mathrm{~s}^{-1}\right)$ based on an empir- 
Table 2. Model values for GPP $\left(\mathrm{MgCha}^{-1} \mathrm{yr}^{-1}\right)$ for the last year (2006) of the ambient air temperature control plot simulation $\left(T_{\text {air }}+0{ }^{\circ} \mathrm{C}\right)$, the control plot simulation $-5^{\circ} \mathrm{C}\left(T_{\text {air }}-5^{\circ} \mathrm{C}\right)$, the control plot simulation $+6^{\circ} \mathrm{C}\left(T_{\text {air }}+6^{\circ} \mathrm{C}\right)$ and the ambient air temperature drought plot simulation $\left(T_{\text {air }}+0^{\circ} \mathrm{C}\right)$. The equivalent temperature is the elevation in the control plot simulation temperature needed to replicate the same magnitude reduction in GPP as the drought simulation, for the year 2006 and at ambient temperatures. The equivalent temperature is derived from a linear relationship between GPP values in 2006 and the air temperatures in the 5 temperature simulations per model.

\begin{tabular}{lrrrrr}
\hline & CLM3.5 & ED2 & JULES & SiB3 & SPA \\
\hline Control GPP $T_{\text {air }}-5^{\circ} \mathrm{C}$ & 40.74 & 31.74 & 36.73 & 35.27 & 38.23 \\
Control GPP $T_{\text {air }}+0{ }^{\circ} \mathrm{C}$ & 36.68 & 28.31 & 31.16 & 31.95 & 29.55 \\
Control GPP $T_{\text {air }}+6{ }^{\circ} \mathrm{C}$ & 28.03 & 20.70 & 20.08 & 27.50 & 15.89 \\
Drought GPP $T_{\text {air }}+0^{\circ} \mathrm{C}$ & 26.47 & 10.79 & 18.13 & 20.86 & 19.55 \\
Equivalent $T_{\text {air }}$ & 8.83 & 17.50 & 8.61 & 15.70 & 4.92 \\
\hline
\end{tabular}

ical relationship calculated from the flux tower at the study site (Doughty, unpublished data). The results on hourly time steps from each model for the period of 2000-2006 for the five temperature simulations (with offset of $-5,+0,+2,+4$ and $+6{ }^{\circ} \mathrm{C}$ ) were pooled. Model output was then placed into $1{ }^{\circ} \mathrm{C}$ bins of $T_{\text {air }}$ for the canopy-scale analysis (GPP, NEE, ecosystem respiration $\left.\left(R_{\text {eco }}\right)\right)$ or of leaf temperature $\left(T_{\text {leaf }}\right)$ for leaf-scale analysis, as done in the DG study. Accounting for non-gaussian distributions in model output, the median and the 15.9th and 84.1th quantiles of the binned model output are plotted to represent the mean and 1 standard deviation of the temperature response curve of any model variable. The data from the drought and control simulations are considered separately.

To explore the relative sensitivity of models to changes in temperature and drought, a linear relationship between the temperature increase per control simulation $(-5,0,2,4$, $6^{\circ} \mathrm{C}$ ) and final year (2006) GPP was used to calculate the change in GPP per $1^{\circ} \mathrm{C}$ increase $T_{\text {air }}$ for each model (Table 2). This value was used to calculate the increase in temperature necessary to produce the same loss of GPP as the ambient $T_{\text {air }}$ drought simulation, where there is a $50 \%$ reduction in wet season rainfall (Table 2).

DG published data for the temperature response of $A_{\mathrm{n}}$ and $g_{\mathrm{s}}$ of sunlit leaves during the dry season when PPFD is $>1000 \mu \mathrm{mol} \mathrm{m}^{-2} \mathrm{~s}^{-1}$. CLM3.5 and SPA are the only models which have separate output for sunlit and shaded leaves. Consequently, data from the sunlit leaves of these models from periods of high PPFD ( $\left.>1000 \mu \mathrm{mol} \mathrm{m}^{-2} \mathrm{~s}^{-1}\right)$ during the dry season (July-December) were used for comparison. The effect of increasing $T_{\text {air }}$ reducing modelled soil water content (via increased VPD and consequent leaf transpiration) had to be removed from the model outputs to make it comparable to the DG data, where individual leaves were artificially warmed. Therefore, we only selected model outputs from the temperature simulations if the soil water con- tent in the rooting zone was in the top quartile of the values from the ambient control simulation, this corresponded to $\beta$ values of $>0.9$ in CLM3.5. For consistency with the sunlit leaf analysis, the analysis of canopy average leaf data from all models was done using dry season data with PPFD $>1000 \mu \mathrm{mol} \mathrm{m}^{-2} \mathrm{~s}^{-1}$.

The relative sensitivity of the five models to changes in temperature and precipitation is assessed by comparing the interactive and non-interactive effects of the $50 \%$ reduction in wet season precipitation (drought simulation) with the -5 , 0 , and $+6{ }^{\circ} \mathrm{C}$ change in $T_{\text {air }}$ on ecosystem fluxes at the end of the 8-year simulation (2006).

\section{Results}

\subsection{Canopy-scale responses}

The models have similar responses of NEE and GPP to increasing $T_{\text {air }}$. DG observed a reduction in carbon uptake as NEE went from $-17.4 \pm 0.3$ to $-7.9 \pm 1.1 \mu \mathrm{mol} \mathrm{m}^{-2} \mathrm{~s}^{-1}$, corresponding to an increase in $T_{\text {air }}$ from 28 to $32^{\circ} \mathrm{C}$ (Fig. 2a). The modelled NEE begins to increase at a lower $T_{\text {air }}\left(22-25^{\circ} \mathrm{C}\right)$ in the models and the $28-32^{\circ} \mathrm{C}$ increase in NEE is generally substantially less than observed by DG $\left(2.5-3.9 \mu \mathrm{mol} \mathrm{m}^{-2} \mathrm{~s}^{-1}\right)$, except in SPA which experiences a similar increase in NEE as DG from 28 to $32{ }^{\circ} \mathrm{C}\left(8.8 \mu \mathrm{mol} \mathrm{m}^{-2} \mathrm{~s}^{-1}\right)$, across the same range of values $\left(-15.8\right.$ to $-7.0 \mu \mathrm{mol} \mathrm{m} \mathrm{m}^{-2} \mathrm{~s}^{-1}$; Fig. 2a). The increase in modelled NEE at high temperatures is caused by a decline in GPP across all models (Fig. 2b). As $T_{\text {air }}$ increases from 16 to $38^{\circ} \mathrm{C}$, the average decline in GPP from all models is $20.9 \pm 3.2 \mu \mathrm{mol} \mathrm{m}^{-2} \mathrm{~s}^{-1}$. In contrast the mean model decline in $R_{\text {eco }}$ over the same modelled $T_{\text {air }}$ range was $4.2 \pm 1.8 \mu \mathrm{mol} \mathrm{m}^{-2} \mathrm{~s}^{-1}$ (Fig. 2c). The decline in modelled ecosystem respiration is low because in all models a decline in autotrophic respiration with increasing temperature (linked in the models with reduced GPP) is opposed by an increase in heterotrophic respiration (data not shown).

Declines in GPP corresponded to declines in LAI. Between 25 and $38^{\circ} \mathrm{C}$, the decline in GPP in CLM3.5 $(89 \pm 38 \%)$, and SPA $(82 \pm 26 \%)$ was greater than in other models (Fig. 2b) and matched by greater declines in LAI over the same temperature range $\left(4.2 \pm 1.0 \mathrm{~m}^{2} \mathrm{~m}^{-2}\right.$, CLM 3.5 and $4.4 \pm 0.9 \mathrm{~m}^{2} \mathrm{~m}^{-2}$ in SPA, relative to only $0.6 \pm 0.3 \mathrm{~m}^{2} \mathrm{~m}^{-2}$ in ED2 and $0.4 \pm 0.1 \mathrm{~m}^{2} \mathrm{~m}^{-2}$ in JULES; Fig. 2d). The intermodel variability in LAI is large; at $25^{\circ} \mathrm{C}$ the median LAI value in $\operatorname{ED} 2\left(3.6 \pm 0.3 \mathrm{~m}^{2} \mathrm{~m}^{-2}\right)$ is 3 times smaller than the median values in CLM3.5 $\left(10.7 \pm 1.0 \mathrm{~m}^{2} \mathrm{~m}^{-2}\right)$. Observed mean LAI at the TNF under non-drought conditions ranged from 5.5 to $6.3 \mathrm{~m}^{2} \mathrm{~m}^{-2}$ in 2000-2005 (Brando et al., 2008) and therefore the modelled values span a range $\sim 70 \%$ above and below the measured LAI (Fig. 2d).

Combined drought and warming had compound effects on GPP, $R_{\text {eco }}$ and LAI. In CLM3.5, GPP remained the same 

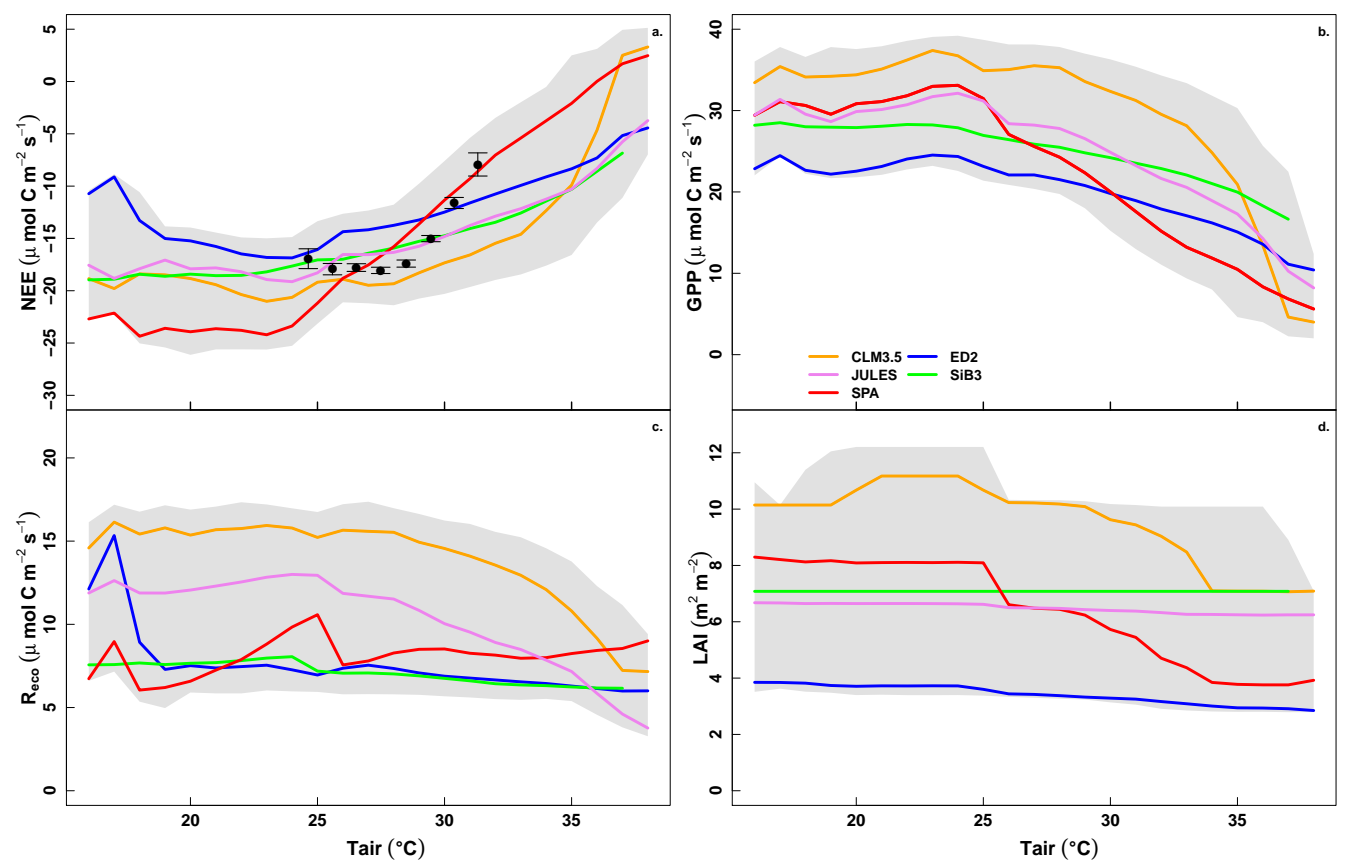

Figure 2. Comparison of the air temperature $\left(T_{\text {air }} ;{ }^{\circ} \mathrm{C}\right)$ response of (a) daytime net ecosystem exchange $\left(\mathrm{NEE} ; \mu \mathrm{mol} \mathrm{m}{ }^{-2} \mathrm{~s}{ }^{-1} ;\right.$ note that negative values of NEE indicate carbon sequestration), (b) gross primary productivity (GPP; $\left.\mu \mathrm{mol} \mathrm{m}^{-2} \mathrm{~s}^{-1}\right),(\mathbf{c})$ ecosystem respiration $\left(R_{\mathrm{eco}}\right.$; $\mu \mathrm{mol} \mathrm{m} \mathrm{m}^{-2} \mathrm{~s}^{-1}$ ), (d) leaf area index (LAI; $\mathrm{m}^{2} \mathrm{~m}^{-2}$ ). The lines show the median model responses from the five control temperature runs per model pooled and divided into $1^{\circ} \mathrm{C}$ temperature bins. The grey shaded area shows the combined 15.9th and 84.1th quantiles for all models. The black points and error bars in panel (a) show the daytime eddy-flux inferred NEE (cf. Fig. 4 in Doughty and Goulden, 2008).
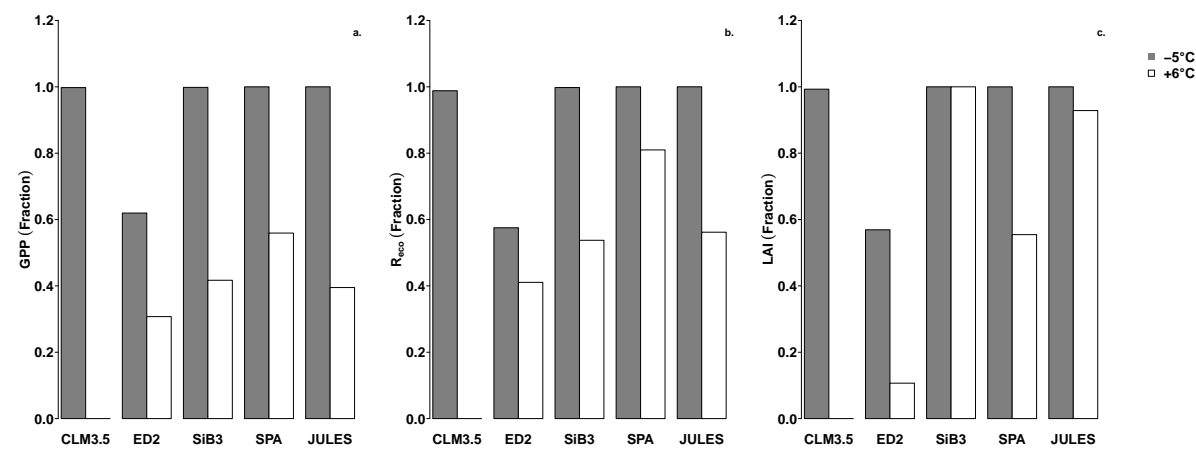

Figure 3. Modelled effect of short-term variations in temperature and drought expressed as 1 minus the changes in (a) gross primary productivity (GPP), (b) ecosystem respiration $\left(R_{\mathrm{eco}}\right)$ and (c) leaf area index (LAI) in the final year (2006) of the drought run, as a fraction of the value of the final year (2006) of the control run, for the $T_{\text {air }}-5^{\circ} \mathrm{C}$ (grey bars) and $T_{\text {air }}+6{ }^{\circ} \mathrm{C}$ (white bars) simulations.

in the $T_{\text {air }}-5^{\circ} \mathrm{C}$ simulation at the end of the drought and control simulation; however, in the $T_{\text {air }}+6^{\circ} \mathrm{C}$ simulation, the forest which existed at the end of the control simulation was replaced with grassland in the drought simulation (GPP values for grassland are not shown; Fig. 3a). In JULES, $\mathrm{SiB} 3$ and SPA, the GPP was the same in the control and the drought simulation at $T_{\text {air }}-5^{\circ} \mathrm{C}$; however, GPP is 61,58 and $44 \%$ lower respectively at the end of the drought relative to the control simulation (Fig. 3a). The combined effect of temperature and drought on GPP and $R_{\text {eco }}$ is lowest in ED2, because it was the only model to have a strong drought effect on GPP, $R_{\text {eco }}$ and LAI in the $T_{\text {air }}-5^{\circ} \mathrm{C}$ simulation (Fig. 3). In CLM3.5 and SPA, GPP and LAI have the same fractional reductions with drought, at higher temperatures (Fig. 3a and c), indicating a tight coupling between the LAI and canopy productivity; this contrasts the lack of or low GPP-LAI feedback in SiB3 and JULES.

Amongst the models there is a continuum of temperature versus drought sensitivity. We express the temperature versus drought sensitivity as the equivalent temperature increase necessary to produce the same GPP reduction as between the last year of the control to the drought simulation at 
ambient $T_{\text {air }}$ (Table 2). A low equivalent temperature would represent a greater GPP sensitivity to temperature increase and/or a lower GPP sensitivity to drought; a higher equivalent temperature represents a lower GPP sensitivity to temperature increase and/or a higher GPP sensitivity to drought. The equivalent temperature increase necessary to reproduce the same GPP reduction as from the last year of control and droughts simulation at ambient temperature was lowest in SPA $\left(4.92^{\circ} \mathrm{C}\right)$, moderate in JULES and CLM3.5 (8.61 and $8.83^{\circ} \mathrm{C}$, respectively), and highest in SiB3 and ED2 (15.70 and $17.50^{\circ} \mathrm{C}$, respectively; Table 2 ). However, across all the models a $5^{\circ} \mathrm{C}$ reduction in ambient $T_{\text {air }}$ resulted in an increase in forest productivity as GPP rose between 3.3 and 8.7 $\mathrm{MgC} \mathrm{ha}^{-1} \mathrm{yr}^{-1}$ in all models (Table 2).

\subsection{Leaf-scale responses}

Leaf-scale $A_{\mathrm{n}}$ and $g_{\mathrm{s}}$ oppose LAI responses; the model with the largest change in LAI in response to temperature increase (CLM3.5) has the lowest $A_{\mathrm{n}}$ values and the models with the smallest change in LAI (ED2, JULES and SiB3) have the greatest $A_{\mathrm{n}}$ values and the strongest responses of $A_{\mathrm{n}}$ to temperature change (Fig. 4). Model uncertainty increases with temperature for $A_{\mathrm{n}}$ and $V_{\text {cmax }}$ (Figs. 4a and 5). For $V_{\text {cmax }}$ this is caused by substantial variation in the optima $\left(10^{\circ} \mathrm{C}\right.$; Fig. 5) and the rate of decline in $V_{\text {cmax }}$ following the optima; in CLM3.5 $V_{\text {cmax }}$ declines $50 \%$ at $9{ }^{\circ} \mathrm{C}$ over the optimum, contrasting with the same decline $17^{\circ} \mathrm{C}$ over the optimum in SPA (Fig. 5).

The optimum $A_{\mathrm{n}}$ in SPA, SiB3, JULES, CLM3.5 and ED2 occurs at $T_{\text {leaf }}$ values of $25,26,27,30$ and $30{ }^{\circ} \mathrm{C}$, respectively (Fig. 4a), and significantly before the optimum point on $V_{\text {cmax }}$ (Fig. 5). In all models the $A_{\mathrm{n}}$ optimum and the initial decline in canopy average $A_{\mathrm{n}}$ is linked to declines in $g_{\mathrm{s}}$ (Fig. 4a-b). Consequently, for each model there are apparent, but variable, relationships between $g_{\mathrm{s}}$ and $A_{\mathrm{n}}$ (Fig. 6), but no obvious relationships between $A_{\mathrm{n}}$ and $V_{\text {cmax }}$ (Fig. 7).

There was high variability in the magnitude and temperature response of $g_{\mathrm{s}}$ across the models. The maximum canopy average $g_{\mathrm{s}}$ values in $\mathrm{SiB} 3\left(486 \mathrm{mmol} \mathrm{m}^{-2} \mathrm{~s}^{-1}\right.$ at $25^{\circ} \mathrm{C}$ ) and ED2 $\left(384 \mathrm{mmol} \mathrm{m}^{-2} \mathrm{~s}^{-1}\right.$ at $\left.23^{\circ} \mathrm{C}\right)$ are substantially higher than CLM3.5 (49 mmol m $\mathrm{m}^{-2} \mathrm{~s}^{-1}$ at $\left.20^{\circ} \mathrm{C}\right)$, JULES $\left(70 \mathrm{mmol} \mathrm{m}^{-2} \mathrm{~s}^{-1}\right.$ at $\left.25^{\circ} \mathrm{C}\right)$ and SPA $\left(200 \mathrm{mmol} \mathrm{m}^{-2} \mathrm{~s}^{-1}\right.$ at $24^{\circ} \mathrm{C}$; Fig. 4b). In CLM3.5 a strong constriction in $E_{\mathrm{t}}$ is caused by the strong influence of $\beta$ on $g_{\mathrm{s}}$ (Fig. $4 \mathrm{c}-\mathrm{d}$ ). $\beta$ is reduced by $85 \pm 31 \%$ in CLM3.5 as $T_{\text {leaf }}$ increase from 30 to $40{ }^{\circ} \mathrm{C}$. The decline in $\beta$ over the same $T_{\text {leaf }}$ range was only $14 \pm 1 \%$ in ED2, $38 \pm 5 \%$ in JULES and $7.9 \pm 1 \%$ in SiB3 (Fig. 4d).

The slope of $A_{\mathrm{n}}$ against $g_{\mathrm{s}}$ indicates intrinsic water use efficiency (IWUE): the rate of increase of assimilation per unit increase in $g_{\mathrm{s}}$. If $A_{\mathrm{n}}$ is plotted against $g_{\mathrm{s}}$ separately for each model temperature simulations $\left(-5,0,+2,+4,+6{ }^{\circ} \mathrm{C}\right)$ and a linear fit is forced through the $g_{\mathrm{s}}$ and $A_{\mathrm{n}}$ data, it is apparent that all models simulate increasing IWUE (an increase in slope) from the $-5^{\circ} \mathrm{C}$ up to the $+6^{\circ} \mathrm{C}$ simulations (Fig. 6 and Table 3). The increase in slope of $A_{\mathrm{n}}$ and $g_{\mathrm{s}}$ from the -5 to $+6{ }^{\circ} \mathrm{C}$ temperature simulation is greater in the drought than control simulations in all models (Fig. 6 and Table 3), suggesting that both increasing temperature and reduced water availability increase IWUE.

When the effect of soil water stress is removed and sunlit leaf-level values are compared to the DG data for the models which could output separate sunlit leaf values of $g_{\mathrm{s}}$ and $A_{\mathrm{n}}$ (only SPA and CLM3.5; Fig. 8), the peak $A_{\mathrm{n}}$ of sunlit leaves in SPA at $25^{\circ} \mathrm{C}\left(8.72 \pm 0.24 \mu \mathrm{mol} \mathrm{m}{ }^{-2} \mathrm{~s}^{-1}\right)$ is similar to the peak in the DG leaf-scale data at $30.5^{\circ} \mathrm{C}$ $\left(8.44 \pm 0.17 \mu \mathrm{mol} \mathrm{m}{ }^{-2} \mathrm{~s}^{-1}\right.$; Fig. 8a). In CLM3.5 the peak $A_{\mathrm{n}}$ at $29^{\circ} \mathrm{C}$ is considerably higher $\left(13.48 \pm 0.20 \mu \mathrm{mol} \mathrm{m}^{-2} \mathrm{~s}^{-1}\right)$, although it occurs at a similar temperature to the observed peak. Both CLM3.5 and SPA show a decline of $A_{\mathrm{n}}$ with temperature similar to the data. Modelled $g_{\mathrm{s}}$, however, shows a poor match to the observations (Fig. 8b). Peak $g_{\mathrm{s}}$ values occur at substantially lower $T_{\text {leaf }}$ values in CLM3.5 $\left(27^{\circ} \mathrm{C}\right)$ and SPA $\left(25^{\circ} \mathrm{C}\right)$ than observed $\left(33.5^{\circ} \mathrm{C}\right.$; Fig. 5b). The peak sunlit $g_{\mathrm{s}}$ in SPA are also significantly higher $\left(434 \pm 88 \mathrm{mmol} \mathrm{m}^{-2} \mathrm{~s}^{-1}\right)$ than the observations $\left(123 \pm 4 \mathrm{mmol} \mathrm{m}^{-2} \mathrm{~s}^{-1}\right)$ and show a very sharp decline not observed in the data (Fig. 8b).

\section{Discussion}

\subsection{Canopy- and leaf-scale feedbacks}

The response of NEE and GPP to short-term changes in temperature demonstrated substantially greater consistency across models than for LAI (Fig. 2). Amongst the models which had dynamic LAI, the change in LAI from the original value ranged from $4.5 \mathrm{~m}^{2} \mathrm{~m}^{-2}$ in SPA to $1.0 \mathrm{~m}^{2} \mathrm{~m}^{-2}$ in ED2. Interestingly, the change of LAI with $T_{\text {air }}$ in ED2 and JULES was so low that it was more comparable to $\mathrm{SiB} 3$, a model with fixed LAI. This is in contrast with CLM3.5 and SPA, within which LAI declined substantially as $T_{\text {air }}$ rose above a threshold (Fig. 2d). The inter-model range in LAI (maximum range $7.5 \mathrm{~m}^{2} \mathrm{~m}^{-2}$ ) was greater than the decline in LAI with $T_{\text {air }}$ in any model. If leaf-scale fluxes are scaled using an inaccurate LAI, the simulation of both accurate leaf- and canopy-scale fluxes is not possible (Bonan et al., 2012; Lloyd et al., 2010; Mercado et al., 2006, 2009). Given the large variability in LAI responses across the models, it would be expected that there should be a greater variability in GPP and NEE than was observed. Therefore, the models must compensate for variability in canopy structural parameters, such as LAI, through adjustment in other leaf-scale parameters if the observed consistency in ecosystem-scale responses is to be maintained (Bonan et al., 2012). We found substantial variation in the magnitude and temperature responses of leafscale parameters: peak $V_{\text {cmax }}$ had a $10^{\circ} \mathrm{C} T_{\text {leaf }}$ range across the models (Fig. 5), $g_{\mathrm{s}}$ values varied by over an order of mag- 
Table 3. Values show the normalised intrinsic water use efficiency (IWUE) calculated from the linear slope of normalised $A_{\mathrm{n}}$ plotted against normalised $g_{\mathrm{s}}$ (Fig. 6). The normalised IWUE is calculated separately for each models' control and drought temperature simulations (ambient air temperature $\left(T_{\text {air }}\right)-5,+0,+2,+4$, and $+6{ }^{\circ} \mathrm{C}$ ). (Note NA in CLM3.5 drought simulations indicates the model changed from a forest to a grassland).

\begin{tabular}{|c|c|c|c|c|c|c|c|c|c|c|}
\hline & \multicolumn{5}{|c|}{ Control simulations } & \multicolumn{5}{|c|}{ Drought simulations } \\
\hline & CLM3.5 & ED2 & JULES & SiB3 & SPA & CLM3.5 & ED2 & JULES & SiB3 & SPA \\
\hline$T_{\text {air }}-5^{\circ} \mathrm{C}$ & 0.84 & 0.42 & 0.50 & 0.09 & 0.49 & 0.73 & 0.29 & 0.50 & 0.10 & 0.27 \\
\hline$T_{\mathrm{air}}+0^{\circ} \mathrm{C}$ & 0.93 & 0.56 & 0.83 & 0.49 & 0.68 & 0.93 & 0.40 & 0.60 & 0.93 & 0.24 \\
\hline$T_{\text {air }}+2^{\circ} \mathrm{C}$ & 1.01 & 0.67 & 1.01 & 0.58 & 0.73 & 1.08 & 0.53 & 0.97 & 1.11 & 0.41 \\
\hline$T_{\text {air }}+4^{\circ} \mathrm{C}$ & 1.05 & 0.79 & 1.18 & 0.65 & 1.00 & NA & 0.78 & 1.37 & 1.20 & 0.74 \\
\hline$T_{\mathrm{air}}+6^{\circ} \mathrm{C}$ & 1.11 & 0.95 & 1.32 & 0.69 & 1.50 & NA & 1.10 & 1.73 & 1.22 & 1.15 \\
\hline
\end{tabular}
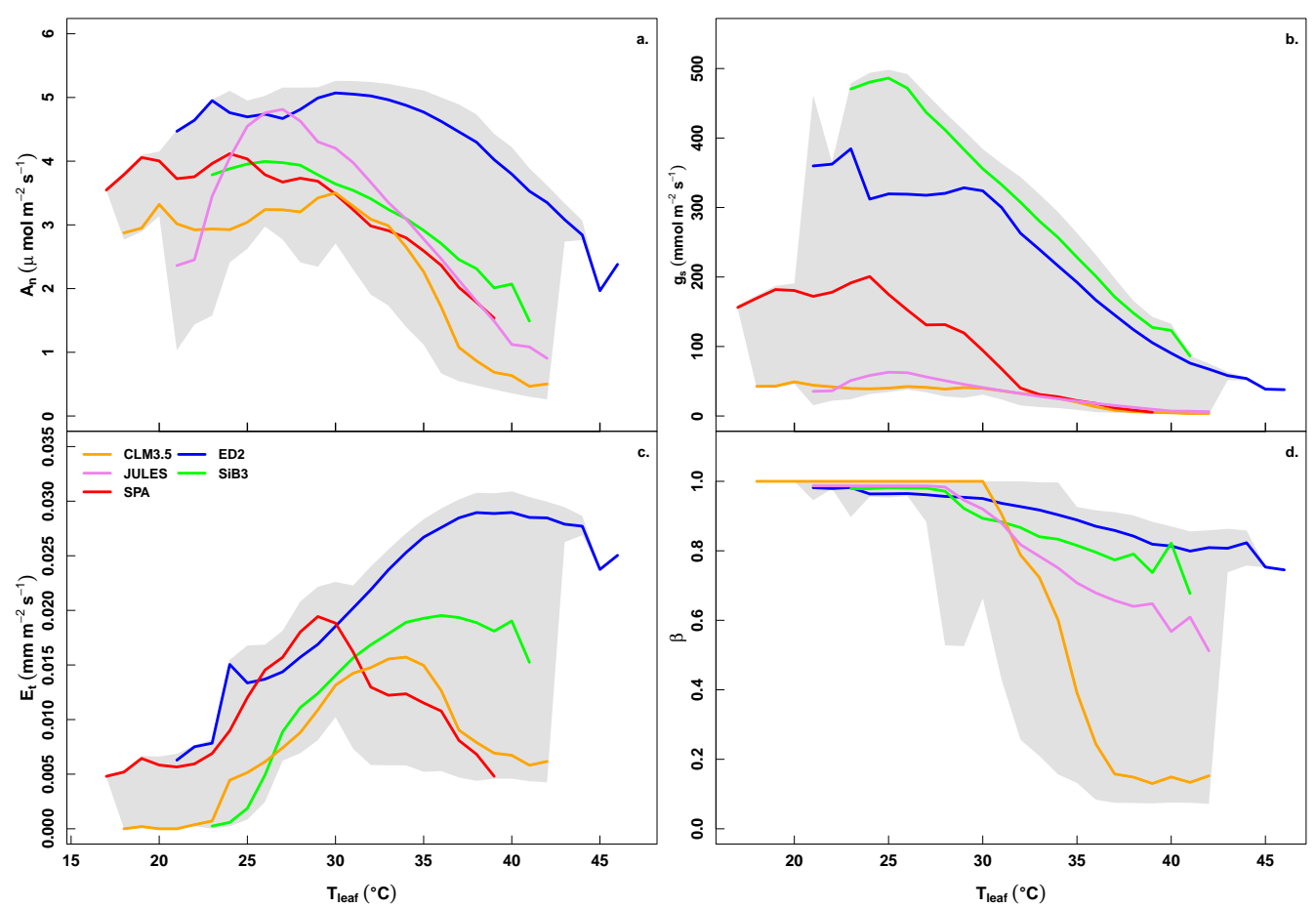

Figure 4. Comparison of the dry season mean (sunlit + shaded leaves, weighted by their respective LAIs) leaf-level response to temperature $\left(T_{\text {leaf }} ;{ }^{\circ} \mathrm{C}\right)$ of (a) net photosynthesis $\left(A_{\mathrm{n}}, \mu \mathrm{mol} \mathrm{m}{ }^{-2} \mathrm{~s}^{-1}\right)$, (b) stomatal conductance $\left(g_{\mathrm{s}}, \mathrm{mmol} \mathrm{m}^{-2} \mathrm{~s}^{-1}\right)$, (c) leaf evapo-transpiration $\left(E_{\mathrm{t}}\right.$, $\mathrm{mm} \mathrm{m}^{-2} \mathrm{~s}^{-1}$ ) and (d) the soil water stress factor $(\beta)$ for average canopy leaves (Note SPA does not simulate $\beta$ ). The lines show the median model responses from the control plot for the five temperature simulations pooled and divided into $1^{\circ} \mathrm{C}$ temperature bins for each model. The grey shaded area shows the combined 15.9th and 84.1th quantiles for all models. (Note JULES $E_{\mathrm{t}}$ data is missing from these simulations).

nitude (Fig. 4b), the inter-model range of $\beta$ and $E_{\mathrm{t}}$ increased with $T_{\text {leaf }}$ (Fig. $4 \mathrm{c}-\mathrm{d}$ ), and there was a twofold increase in the inter-model range of $A_{\mathrm{n}}$ as $T_{\text {leaf }}$ rose from 25 to $40^{\circ} \mathrm{C}$ (Fig. 4a). Such variability across the models suggests that any similarity in the response of NEE to $T_{\text {air }}$ among models is caused by different processes and feedbacks at the leaf scale. Had the models been run to their equilibrium states, it is likely that there would have been greater divergence of model responses at both canopy- and leaf-scales. Prolonged higher temperatures reduce long-term moisture availability and cause more severe changes in $\beta$; in dynamic PFT models this can result in a substantial shift of PFT away from tropical forest. Without more data to evaluate which models produced the correct responses to temperature, it is hard to have confidence in predictions of climate change impacts in Amazonian. Variability in the control of $g_{\mathrm{s}}$ and leaf biochemistry on $A_{\mathrm{n}}$ and changes in IWUE efficiency with increasing temperature or drought will have significant consequences on the demand of water from a forest (Harper et al., 2014). In this study we find $g_{\mathrm{s}}$ had a greater control on the change in $A_{\mathrm{n}}$ with increasing temperature because $A_{\mathrm{n}}$ started to decline at $T_{\text {leaf }}$ values which were lower than those at which peak $V_{\mathrm{cmax}}$ 


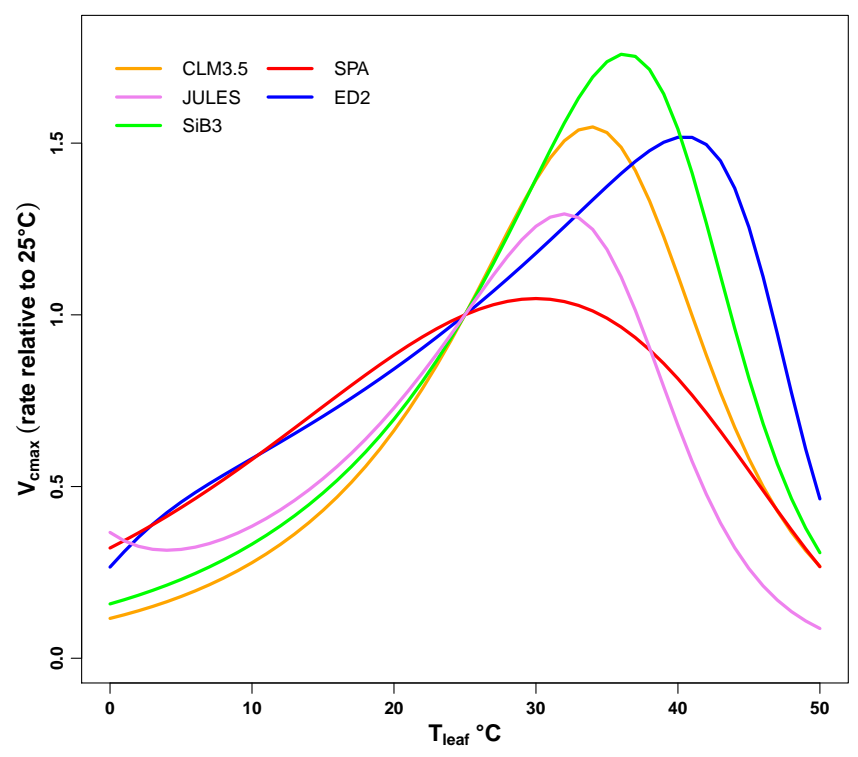

Figure 5. The temperature response of $V_{\mathrm{cmax}}$ for each model shown relative to the $V_{\mathrm{cmax}}$ at $25^{\circ} \mathrm{C}$ per model.

occurred (Figs. $4 \mathrm{~b}$ and 5), and $A_{\mathrm{n}}$ maintained a positive relationship with $g_{\mathrm{s}}$ across all models (Table 3; Fig. 6), but no clear relationship with $V_{\text {cmax }}$ (Fig. 7). All the models in this study also predicted an increases in IWUE from the lowest (ambient $T_{\text {air }}-5^{\circ} \mathrm{C}$ ) to the highest (ambient $T_{\text {air }}+6^{\circ} \mathrm{C}$ ) temperature simulation; this increase in IWUE was also always greater in the drought temperature simulations relative to the control temperature simulations (Table 3; Fig. 6). Increases in IWUE with increasing temperature suggests that as the ecosystem warms $A_{\mathrm{n}}$ will become more sensitive to reductions in $g_{\mathrm{s}}$ and $g_{\mathrm{s}}$ will maintain a greater control on $A_{\mathrm{n}}$ than biochemical controls, even at very extreme increases in temperature (ambient $T_{\text {air }}+6^{\circ} \mathrm{C}$ ).

These results are consistent with the hypothesis that temperature increases will mainly be manifest through the effect of increased VPD on stomatal conductance (Lloyd and Farquhar, 2008). They are also consistent with leaf warming data from the Tapajós forest which show that reductions in $A_{\mathrm{n}}$ start to occur at $4-5^{\circ} \mathrm{C}$ before the optimum point for $V_{\text {cmax }}$ and $J_{\max }$ in sunlit leaves (Tribuzy, 2005). However, the responses from longer-term leaf warming experiments at the same site showed that changes in leaf biochemistry with increasing leaf temperatures were an important control on $A_{\mathrm{n}}$ (Doughty, 2011), suggesting more data are required to test effectively both the short- and long-term responses of $A_{\mathrm{n}}$ to changes in temperature in models.

Comparing the short-term direct effect of temperature on the $A_{\mathrm{n}}-g_{\mathrm{s}}$ relationships is complicated because of the differences in the calculation and implementation of the effect of water stress amongst models (Powell et al., 2013; Zhou et al., 2013). $\beta$ is altered by changes in SWC, which can be caused by changes in temperature (via increased VPD alter- ing SWC), as well as changes in precipitation; in turn $\beta$ alters both $g_{\mathrm{s}}$ (Fig. S1) and $A_{\mathrm{n}}$. The decrease in $\beta$ with temperature increase was highly variable among models (Fig. 4d). Consequently, the direct influence of soil water stress on $g_{\mathrm{s}}, A_{\mathrm{n}}$ and $E_{\mathrm{t}}$, versus the indirect effect of VPD, was inconsistent between models. Resolving these inconsistencies is important, as water stress functions impact the ratio of modelled latent to sensible heat fluxes and so when coupled to global climate models they alter climate and vegetation feedbacks (Harper et al., 2014). Improving how water stress is simulated in models is therefore essential to improving temperature and drought responses in tropical forests.

When focusing only on periods of high soil water content and therefore removing the effects of water stress, $A_{\mathrm{n}}$ and $g_{\mathrm{s}}$ values from fully sunlit leaves still varied substantially from the response and magnitude of the DG data (Fig. 8). Given the DG data were averaged from only three top-canopy species, some degree of variation between the model and the data is expected. The variability between the peak data and peak model $g_{\mathrm{s}}$ was, however, $>4$ times (Fig. 8b) and the modelled temperature optima for $g_{\mathrm{s}}\left(25-27^{\circ} \mathrm{C}\right)$ was substantial lower than observed by DG $\left(33.5^{\circ} \mathrm{C}\right)$. Given that CLM3.5 and SPA are in the lower range of the total model variability for the $g_{\mathrm{s}}$ and $A_{\mathrm{n}}$ of an average canopy leaf (aggregated sunlit and shaded leaf; Fig. 4a-b), the variation from the data is likely to be substantially larger if sunlit leaf data could be extracted from all models. Considering the importance of $g_{\mathrm{s}}$ in controlling leaf productivity, the suitability of the empirical models of $g_{\mathrm{s}}$ used in these models requires further testing (Bonan et al., 2014). The use of optimised rather than empirical models may provide an opportunity to improve the capability to simulate $g_{\mathrm{s}}$ responses to temperature and water stress in greater detail (Heroult et al., 2013; Medlyn et al., 2013, 2011; Zhou et al., 2013).

\subsection{Combined drought and temperature sensitivities}

Previous modelling studies have shown that there is high variability in how sensitive models are to temperature and drought (Friedlingstein et al., 2006; Galbraith et al., 2010; Luo et al., 2008; Sitch et al., 2008), but that vegetation models have embedded in them greater sensitivity to rises in temperature than drought (Galbraith et al., 2010) despite the evidence for strong drought sensitivity in natural rainforests (Gatti et al., 2014). The responses of modelled forest production in this study to combined changes in precipitation and temperature were, however, highly variable. CLM3.5 and SPA had very strong compound effects of temperature on drought-induced reductions in GPP, $R_{\text {eco }}$ and LAI (Fig. 3) relative to JULES and SiB3. In ED2, the drought effect on GPP was always stronger than the temperature effect (Fig. 3) because it has a strong drought-mortality effect at this site (Powell et al., 2013). This study demonstrates that there is a continuum in model responses from models that require a low increase in ambient $T_{\text {air }}$ to cause the same GPP loss 

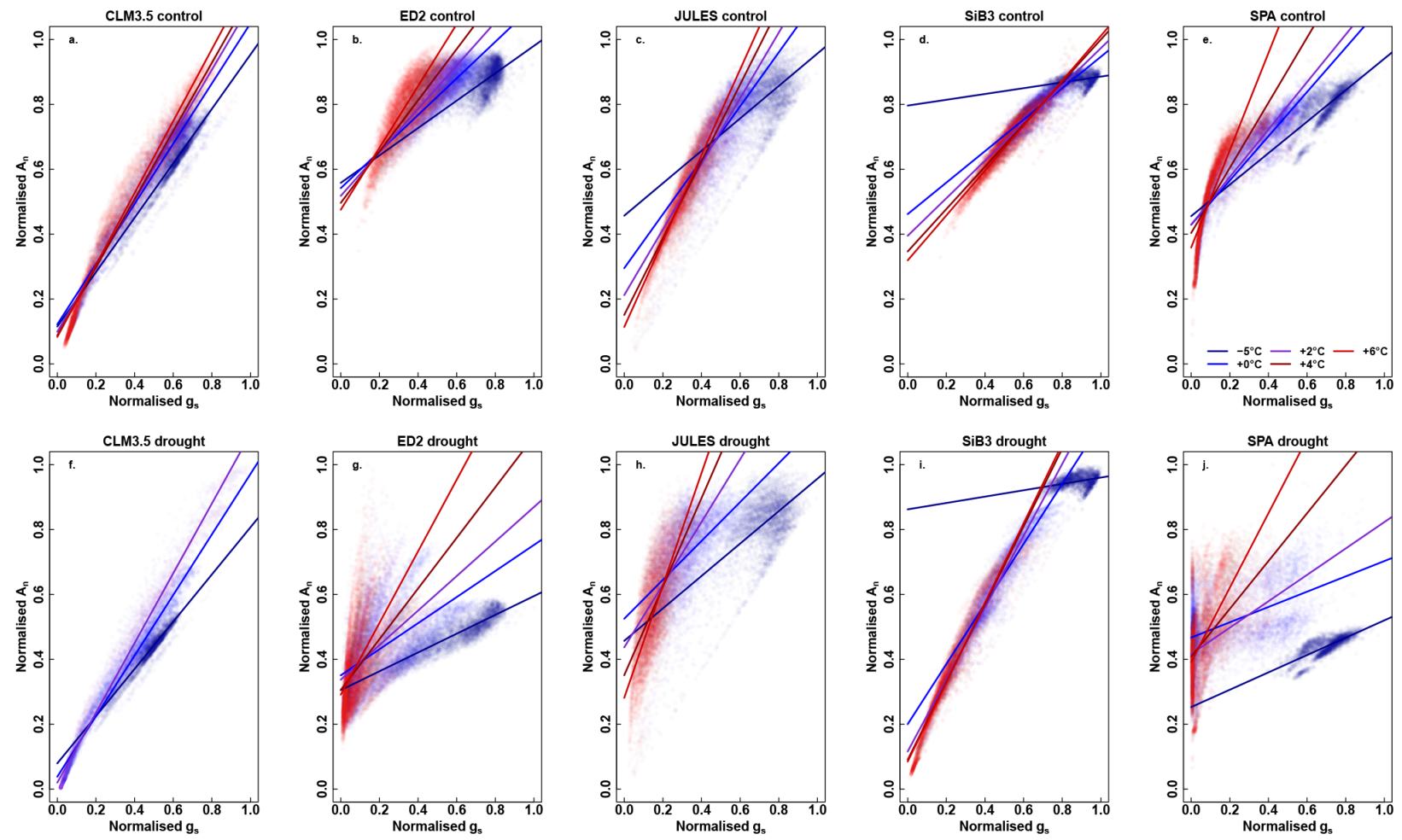

Figure 6. The relationship between 30 min values of modelled stomatal conductance $\left(g_{\mathrm{s}}\right)$ and photosynthesis $\left(A_{\mathrm{n}}\right)$ normalised by their respective maximum values; $A_{\mathrm{n}}$ and $g_{\mathrm{s}}$ values are taken only from the dry season when PPFD $>1000 \mu \mathrm{mol} \mathrm{m}^{-2} \mathrm{~s}^{-1}$. Values are coloured separately from deep blue to red (see legend) for each temperature simulations (ambient air temperature $-5,+0,+2,+4$, and $+6{ }^{\circ} \mathrm{C}$ ) and panels separate the control (panels a-e) and drought simulations (panels $\mathbf{f}-\mathbf{j}$ ), for each model. Values are from sunlit and shaded leaves, weighted by their respective LAIs. A separate linear line is plotted through the normalised $A_{\mathrm{n}}, g_{\mathrm{s}}$ data for each temperature simulations, the slope of which represents the normalised intrinsic water use efficiency: the normalised increase in $A_{n}$ per unit increase in normalised $g_{\mathrm{s}}$. Linear lines are also coloured from deep blue to deep red to differentiate the additions to ambient air temperature (see legend).
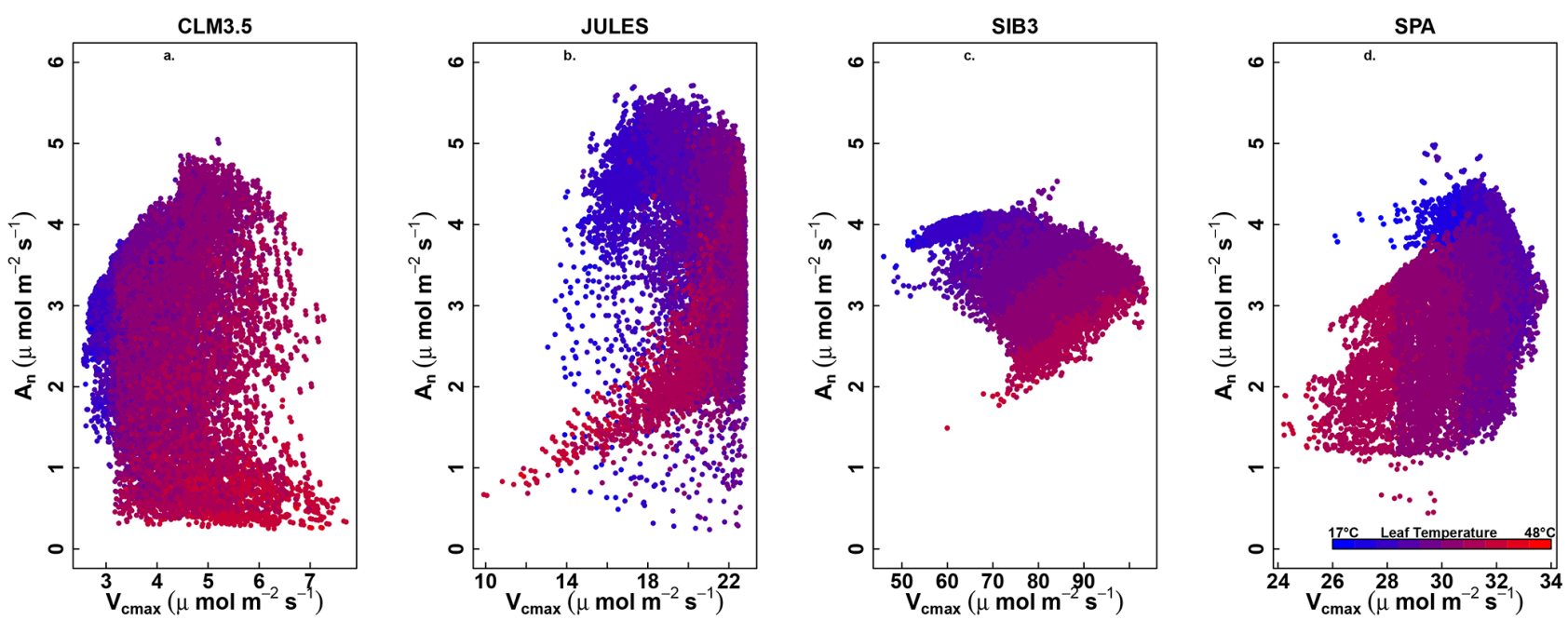

Figure 7. The relationship between $V_{\mathrm{cmax}}\left(\mu \mathrm{mol} \mathrm{m} \mathrm{m}^{-2} \mathrm{~s}^{-1}\right)$ and photosynthesis $\left(A_{\mathrm{n}} \mathrm{mmol} \mathrm{m} \mathrm{s}^{-2}\right)$ for the half hourly output from each model in the dry season of the control runs, with PPFD $>1000 \mu \mathrm{mol} \mathrm{m}^{-2} \mathrm{~s}^{-1}$. Values are from sunlit and shaded leaves, weighted by their respective LAIs. Results are shown across all leaf temperatures explored in this study (colour change from blue to red indicates increasing leaf temperature; see legend). 


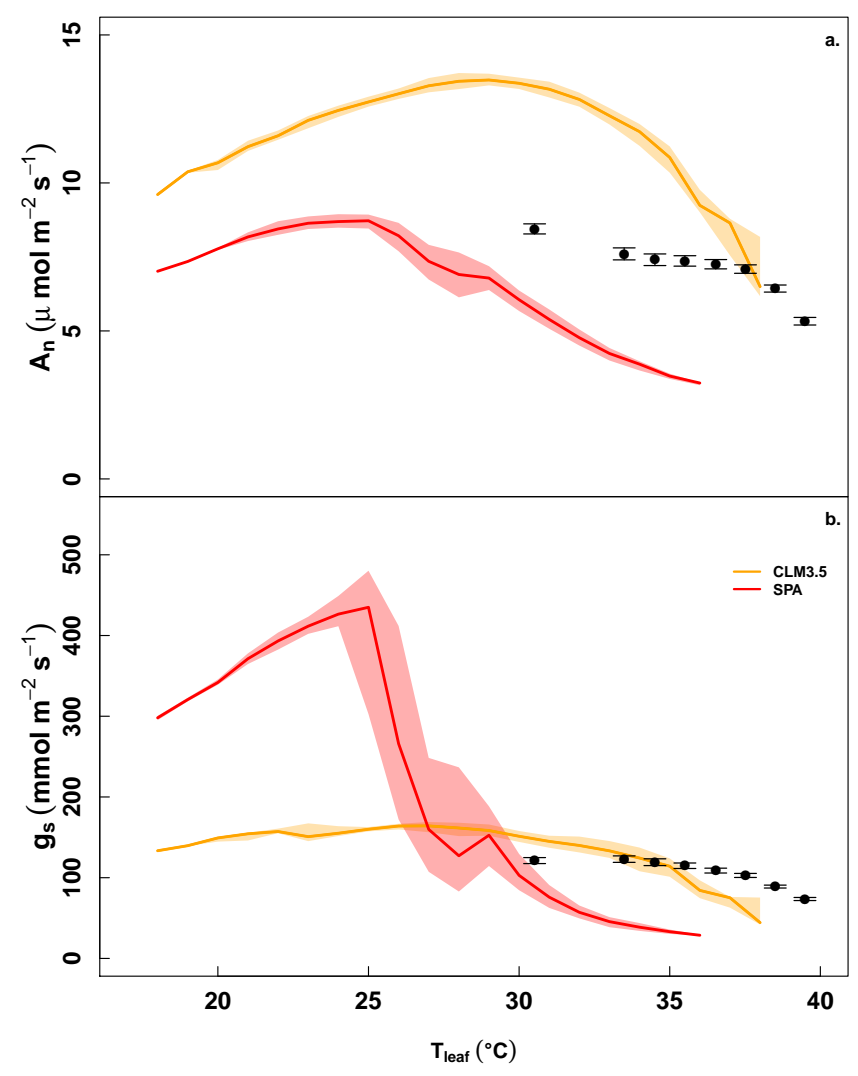

Figure 8. The sunlit leaf-level response of dry season (a) net photosynthesis $\left(A_{\mathrm{n}}, \mu \mathrm{mol} \mathrm{m}{ }^{-2} \mathrm{~s}^{-1}\right)$ and (b) stomatal conductance $\left(g_{\mathrm{s}}\right.$, $\left.\mu \mathrm{mol} \mathrm{m}{ }^{-2} \mathrm{~s}^{-1}\right)$ to leaf temperature $\left(T_{\text {leaf }} ;{ }^{\circ} \mathrm{C}\right)$ for CLM3.5 (orange) and SPA (red). The lines show the median model responses from the control plot for the five temperature simulations pooled and divided into $1{ }^{\circ} \mathrm{C}$ temperature bins for each model. The shaded areas around each line show the 15.9th and 84.1th quantiles for each model. Data from Doughty and Goulden is shown as black points; error bars show the standard error. (Note only SPA and CLM3.5 output data on sunlit leaf values of $A_{\mathrm{n}}$ and $g_{\mathrm{s}}$.)

as a $50 \%$ reduction in wet season rainfall $\left(\mathrm{SPA}, 4.9^{\circ} \mathrm{C}\right)$, to models that have a very strong drought response and therefore require a substantial increase in ambient $T_{\text {air }}$ to replicate the same GPP loss as a $50 \%$ reduction in wet season rainfall (ED2, $17.5^{\circ} \mathrm{C}$; Table 2). As a $6{ }^{\circ} \mathrm{C}$ rise in temperature and a $50 \%$ reduction in rainfall are changes which may occur in Amazonia during the 21st century (Christensen et al., 2007; Collins et al., 2013), we suggest that there is currently no consensus among vegetation models as to whether there will be a stronger drought or temperature response to future climate change within tropical forests.

Across all the models GPP increased when ambient $T_{\text {air }}$ was reduced by $5^{\circ} \mathrm{C}$; this occurred because the ambient air temperature $-5^{\circ} \mathrm{C}$ was closer to the modelled $g_{\mathrm{s}}$ optima. This result suggests models are currently predicting that Amazonian forests are operating beyond a temperature and VPD optimum. Given that the models underestimate the point at which NEE declines with $T_{\text {air }}$ by $3-6^{\circ} \mathrm{C}$ and the point at which $g_{\mathrm{s}}$ declines with $T_{\text {leaf }}$ by $7.5-9.5^{\circ} \mathrm{C}$ (Figs. 2 and 4), it seems likely that the models in this study may be biased towards temperature calibrations for temperate ecosystems. Consequently, as well as moving towards implementing more mechanistic responses to improve models, more research to test and adjust their temperature responses in tropical ecosystem is necessary. The range of model responses in this study is likely to stem from real uncertainty in our understanding of the responses by tropical rain forest ecosystems to changes in precipitation and temperature. Further analysis of the same questions using models that vary in complexity (e.g. statistical or optimised models, as well as purely mechanistic) might provide additional insight into mechanistic and simulation bias (systematic or random), as well advancing understanding about climate risk that we derive from them (Meir et al., 2015).

\section{Conclusions}

This is the first study in which canopy and leaf temperature responses from multiple vegetation models are analysed and compared to existing data on leaf and canopy temperature responses from a tropical forest site. This study finds models lie along a continuum of those which have a greater sensitivity of GPP to changes in temperature relative to drought and those which have a greater sensitivity to drought relative to a change in temperature. Any consistency in model responses to temperature and drought were however, the result of inconsistent leaf-scale responses, which were found to compensate for substantial inter-model variation in the magnitude and response of LAI to drought and temperature.

All the models in this study predict that reductions in $A_{\mathrm{n}}$ are dominated by stomatal rather than biochemical responses and that IWUE increased with rising temperatures. The dominance of the effect of $g_{\mathrm{s}}$ rather than $V_{\mathrm{cmax}}$ on $A_{\mathrm{n}}$ results in all the models predicting greater forest productivity when temperatures are $5{ }^{\circ} \mathrm{C}$ below ambient and closer the temperature of the $g_{\mathrm{s}}$ optimum. This suggests that currently models predict that tropical forests are operating beyond a temperature and VPD optimum, but we note that these predictions may be influenced by parameterisations derived originally from temperate zone forests.

This study concludes that to simulate effectively the response of the Amazon forest to changes in multiple climatic factors substantial improvements are needed in how leafscale processes and leaf-to-canopy scaling are simulated. Further observational data are also required to generate consistent leaf- and canopy-scale data for independent model evaluation.

The Supplement related to this article is available online at doi:10.5194/gmd-8-1097-2015-supplement. 
Author contributions. L. Rowland and M. Williams designed the experiment, performed simulations, analysed data and prepared the manuscript. A. Harper, B. O. Christoffersen, D. R. Galbraith, H. M. A. Imbuzeiro, T. L. Powell, S. R. Saleska, P. R. Moorcroft performed simulation, contributed to study design and prepared manuscript. C. Doughty contributed to the data analysis. N. M. Levine and Y. Malhi contributed to the study design. P. Meir contributed to data analysis and prepared the manuscript.

Acknowledgements. This research was enabled by a grant from the Andes-Amazon Initiative of The Gordon and Betty Moore Foundation. L. Rowland gratefully acknowledges financial support from the Natural Environment Research Council (UK) for a NERC PhD studentship, and NERC grant NE/J011002/1; PM also acknowledges support from ARC FT110100457. L. Rowland would also like to thank, L. Smallman and T. Hill for their help and support. L. Rowland would also like to thank the reviewer Nicolas Delbart and the editor Hisashi Sato for their valuable contribution to improving the quality of this manuscript.

Edited by: H. Sato

\section{References}

Baker, I. T., Prihodko, L., Denning, A. S., Goulden, M., Miller, S., and da Rocha, H. R.: Seasonal drought stress in the Amazon: Reconciling models and observations, J. Geophys. Res.-Biogeo., 113, G00B01, doi:10.1029/2007JG000644, 2008.

Best, M. J., Pryor, M., Clark, D. B., Rooney, G. G., Essery, R .L. H., Ménard, C. B., Edwards, J. M., Hendry, M. A., Porson, A., Gedney, N., Mercado, L. M., Sitch, S., Blyth, E., Boucher, O., Cox, P. M., Grimmond, C. S. B., and Harding, R. J.: The Joint UK Land Environment Simulator (JULES), model description Part 1: Energy and water fluxes, Geosci. Model Dev., 4, 677-699, doi:10.5194/gmd-4-677-2011, 2011.

Bonan, G. B., Levis, S., Sitch, S., Vertenstein, M., and Oleson, K. W.: A dynamic global vegetation model for use with climate models: concepts and description of simulated vegetation dynamics, Global Change Biol., 9, 1543-1566, 2003.

Bonan, G. B., Oleson, K. W., Fisher, R. A., Lasslop, G., and Reichstein, M.: Reconciling leaf physiological traits and canopy flux data: Use of the TRY and FLUXNET databases in the Community Land Model version 4, J. Geophys. Res., 117, G02026, doi:10.1029/2011JG001913, 2012.

Bonan, G. B., Williams, M., Fisher, R. A., and Oleson, K. W.: Modeling stomatal conductance in the earth system: linking leaf water-use efficiency and water transport along the soil-plantatmosphere continuum, Geosci. Model Dev., 7, 2193-2222, doi:10.5194/gmd-7-2193-2014, 2014.

Brando, P. M., Nepstad, D. C., Davidson, E. A., Trumbore, S. E., Ray, D., and Camargo, P.: Drought effects on litterfall, wood production and belowground carbon cycling in an Amazon forest: results of a throughfall reduction experiment, Philos. T. R. Soc. B, 363, 1839-1848, 2008.

Christensen, J. H., Hewitson, B., Busuioc, A., Chen, C., Gao, X., Held, I., Jones, R., Kolli, R. K., Kwon, W. T., Laprise, R.,
Rueda, V. M., Mearns, L., Menéndez, C. G., Räisänen, J., Rinke, A., Sarr, A., Whetton, P., Arritt, R., Benestad, R., Bromwich, D., Caya, D., Comiso, J., de Elía, R., Dethloff, K., Emori, S., Feddema, S., Gerdes., R, González-Rouco, J. F., Gutowski, W., Hanssen-Bauer, I., Jones, C., Katz, R., Kitoh, A., Knutti, R., Leung, R., Lowe. J., Lynch, A. H., Matulla, C., McInnes, K., Mescherskaya, A. V., Mullan, A. B., New, M., Nokhandan, M. H., Pal, J. S., Plummer, D. Rummukainen, M., Schär, C., Stone, D. A., Suppiah, R., Tadross, M., Tebaldi, C., Tennant, W., Widmann, M., and Wilby, R.: Regional Climate Projections, in: Climate Change 2007: the physical science basis. Contribution of working group I to the Fourth Assessment Report of the Intergovernmenatal Panel on Climate Change, edited by: Solomon, S., Quin, D., Manning, M., Chen, Z., Marquies, M., Averyt, K., Tignor, M., and Miller, H., 1, Cambridge University Press, Cambridge, UK, New York, NY, 2007.

Clark, D. B., Mercado, L. M., Sitch, S., Jones, C. D., Gedney, N., Best, M. J., Pryor, M., Rooney, G. G., Essery, R. L. H., Blyth, E., Boucher, O., Harding, R. J., Huntingford, C., and Cox, P. M.: The Joint UK Land Environment Simulator (JULES), model description - Part 2: Carbon fluxes and vegetation dynamics, Geosci. Model Dev., 4, 701-722, doi:10.5194/gmd-4-701-2011, 2011.

Collatz, G. J., Ball, J. T., Grivet, C., and Berry, J. A.: Physiological and Environmental-Regulation of Stomatal Conductance, Photosynthesis and Transpiration - a Model That Includes a Laminar Boundary-Layer, Agr. Forest Meteorol., 54, 107-136, 1991.

Collins, M., Knutti, K., Arblaster, J., Dufresne, J., Fichefet, T., Friedlingstein, P., Gao, X., Gutowski Jr, W. J., Johns, T., Krinner, G., Shongwe, M., Tebaldi, C., Weaver, A. J., Wehner, M., Allen, M. R., Andrews, T., Beyerle, U., Cecilia, M. B., Bony, S., Booth, B. B. B., Brooks, H. E., Brovkin, V., Browne, O., Brutel-Vuilmet, C., Cane, M., Chadwick, R., Cook, E., Cook, K. H., Eby, M., Fasullo, J., Fischer, E. M., Forest, C. E., Forster, P., Good, Goosse, H., Gregory, J. M., Hegerl, G. C., Hezel, P. J., Hodges, K. I., Holland, M. M., Huber, M., Huybrechts, P., Joshi, M., Kharin, V., Kushnir, Y., Lawrence, D. M., Lee, R. W., Liddicoat, S., Lucas, C., Lucht, W., Marotzke, M., Massonnet, F., Matthews, H. D., Meinshausen, M., Morice, C., Otto, A., Patricola, C. M., Berthier, C. P., Prabhat, P., Rahmstorf, S., Riley, W. J., Rogelj, J., Saenko, O., Seager, R., Sedlek, J., Shaffrey, L. C., Shindell, D., Sillmann, J., Slater, A., Stevens, B., Stott, P. A., Webb, R., Zappa, G., and Zickfeld, K.: Long-term Climate Change: Projections, Comitments and Irreversibility, in: Climate Change 2013: The Physical Science Basis Contribution of Working Group I to the Fifth Assessment Report of the Intergovernmental Panel on Climate Change, edited by: Stocker, T. F., Qin, D., Plattner, G.K., Tignor, M., Allen, S. K., Boschung, J., Nauels, A., Xia, Y., Bex, V., and Midgley, P. M., Cambridge University Press, Cambridge, United Kingdon and New York, NY USA, 2013.

Corlett, R. T.: Impacts of warming on tropical lowland rainforests, Trends Ecol. Evol., 26, 606-613, 2011.

Cox, P. M., Huntingford, C., and Harding, R. J.: A canopy conductance and photosynthesis model for use in a GCM land surface scheme, J. Hydrol., 212, 79-94, 1998.

Cox, P. M., Harris, P. P., Huntingford, C., Betts, R. A., Collins, M., Jones, C. D., Jupp, T. E., Marengo, J. A., and Nobre, C. A.: Increasing risk of Amazonian drought due to decreasing aerosol pollution, Nature, 453, 212-215, doi:10.1038/nature06960, 2008. 
da Costa, A. C. L., Galbraith, D., Almeida, S., Portela, B. T. T., da Costa, M., Silva, J. D., Braga, A. P., de Goncalves, P. H. L., de Oliveira, A. A. R., Fisher, R., Phillips, O. L., Metcalfe, D. B., Levy, P., and Meir, P.: Effect of $7 \mathrm{yr}$ of experimental drought on vegetation dynamics and biomass storage of an eastern Amazonian rainforest, New Phytol., 187, 579-591, doi:10.1111/j.14698137.2010.03309, 2010.

da Costa, A. C. L., Metcalfe, D. B., Doughty, C. E., de Oliveira, A. A. R., Neto, G. F. C., da Costa, M. C., Silva, J. D., Aragao, L. E. O. C., Almeida, S., Galbraith, D. R., Rowland, L. M., Meir, P., and Malhi, Y.: Ecosystem respiration and net primary productivity after 8-10 years of experimental through-fall reduction in an eastern Amazon forest, Plant Ecol. Divers., 7, 7-24, 2014.

Doughty, C. E.: An In Situ Leaf and Branch Warming Experiment in the Amazon, Biotropica, 43, 658-665, 2011.

Doughty, C. E. and Goulden, M. L.: Are tropical forests near a high temperature threshold?, J. Geophys. Res., 113, G00B07, doi:10.1029/2007JG000632, 2008.

Farquhar, G. D. and Sharkey, T. D.: Stomatal Conductance and Photosynthesis, Ann. Rev. Plant Phys., 33, 317-345, 1982.

Farquhar, G. D., Caemmerer, S. V., and Berry, J. A.: A BiochemicalModel of Photosynthetic Co2 Assimilation in Leaves of C-3 Species, Planta, 149, 78-90, 1980.

Fisher, R. A., Williams, M., Do Vale, R. L., Da Costa, A. L., and Meir, P.: Evidence from Amazonian forests is consistent with isohydric control of leaf water potential, Plant Cell Environ., 29, 151-165, 2006.

Fisher, R. A., Williams, M., Da Costa, A. L., Malhi, Y., Da Costa, R. F., Almeida, S., and Meir, P.: The response of an Eastern Amazonian rain forest to drought stress: results and modelling analyses from a throughfall exclusion experiment, Global Change Biol., 13, 2361-2378, 2007.

Friedlingstein, P., Cox, P., Betts, R., Bopp, L., Von Bloh, W., Brovkin, V., Cadule, P., Doney, S., Eby, M., Fung, I., Bala, G., John, J., Jones, C., Joos, F., Kato, T., Kawamiya, M., Knorr, W., Lindsay, K., Matthews, H. D., Raddatz, T., Rayner, P., Reick, C., Roeckner, E., Schnitzler, K. G., Schnur, R., Strassmann, K., Weaver, A. J., Yoshikawa, C., and Zeng, N.: Climate-carbon cycle feedback analysis: Results from the C(4)MIP model intercomparison, J. Climate, 19, 3337-3353, 2006.

Gatti, L. V., Gloor, M., Miller, J. B., Doughty, C. E., Malhi, Y., Domingues, L. G., Basso, L. S., Martinewski, A., Correia, C. S. C., Borges, V. F., Freitas, S., Braz, R., Anderson, L. O., Rocha, H., Grace, J., Phillips, O. L., and Lloyd, J.: Drought sensitivity of Amazonian carbon balance revealed by atmospheric measurements, Nature, 506, p. 76, doi:10.1038/Nature12957, 2014.

Galbraith, D., Levy, P. E., Sitch, S., Huntingford, C., Cox, P., Williams, M., and Meir, P.: Multiple mechanisms of Amazonian forest biomass losses in three dynamic global vegetation models under climate change, New Phytol., 187, 647-665, 2010.

Good, P., Jones, C., Lowe, J., Betts, R., and Gedney, N.: Comparing Tropical Forest Projections from Two Generations of Hadley Centre Earth System Models, HadGEM2-ES and HadCM3LC, J. Climate, 26, 495-511, 2013.

Goudriaan, J.: Crop micrometeorology: A simulation study, Center for Agricultural Publishing and Documentation, Wageningen, The Netherlands, 1977.

Goulden, M. L., Miller, S. D., da Rocha, H. R., Menton, M. C., de Freitas, H. C., Figueira, A. M. E. S., and de Sousa, C. A. D.:
Diel and seasonal patterns of tropical forest $\mathrm{CO} 2$ exchange, Ecol. Appl., 14, S42-S54, 2004.

Harper, A., Baker, I. T., Denning, A. S., Randall, D. A., Dazlich, D., and Branson, M.: Impact of Evapotranspiration on Dry Season Climate in the Amazon Forest, J. Climate, 27, 574-591, 2014.

Heroult, A., Lin, Y. S., Bourne, A., Medlyn, B. E., and Ellsworth, D. S.: Optimal stomatal conductance in relation to photosynthesis in climatically contrasting Eucalyptus species under drought, Plant Cell Environ., 36, 262-274, 2013.

Jupp, T. E., Cox, P. M., Rammig, A., Thonicke, K., Lucht, W., and Cramer, W.: Development of probability density functions for future South American rainfall, New Phytol., 187, 682-693, 2010.

Kim, Y., Knox, R. G., Longo, M., Medvigy, D., Hutyra, L. R., Pyle, E. H., Wofsy, S. C., Bras, R. L., and Moorcroft, P. R.: Seasonal carbon dynamics and water fluxes in an Amazon rainforest, Global Change Biol., 18, 1322-1334, 2012.

Kirschbaum, M. U. F. and Farquhar, G. D.: TemperatureDependence of Whole-Leaf Photosynthesis in EucalyptusPauciflora Sieb Ex Spreng, Austr. J. Plant Physiol., 11, 519-538, 1984.

Levis, S., Bonan, G., Vertenstein, M., and Oleson, K.: The Community Land Model Dynamic Global Vegetation Model (CLMDGVM): technical description and user's guide, Boulder, CO, USA, National Center for Atmospheric Research, 2004.

Lloyd, J. and Farquhar, G. D.: Effects of rising temperatures and [CO2] on the physiology of tropical forest trees, Philos. Trans. R. Soc. Lond. B Sci., 363, 1811-1817, 2008.

Lloyd, J., Patiño, S., Paiva, R. Q., Nardoto, G. B., Quesada, C. A., Santos, A. J. B., Baker, T. R., Brand, W. A., Hilke, I., Gielmann, H., Raessler, M., Luizão, F. J., Martinelli, L. A., and Mercado, L. M.: Optimisation of photosynthetic carbon gain and within-canopy gradients of associated foliar traits for Amazon forest trees, Biogeosciences, 7, 1833-1859, doi:10.5194/bg-71833-2010, 2010.

Luo, Y., Gerten, D., Le Maire, G., Parton, W. J., Weng, E., Zhou, X., Keough, C., Beier, C., Ciais, P., Cramer, W., Dukes, J. S., Emmett, B., Hanson, P. J., Knapp, A., Linder, S., Nepstad, D. A. N., and Rustad, L.: Modeled interactive effects of precipitation, temperature, and [CO2] on ecosystem carbon and water dynamics in different climatic zones, Global Change Biol., 14, 1986-1999, 2008.

Malhi, Y., Aragao, L. E., Galbraith, D., Huntingford, C., Fisher, R., Zelazowski, P., Sitch, S., McSweeney, C., and Meir, P.: Exploring the likelihood and mechanism of a climate-change-induced dieback of the Amazon rainforest, Proc. Natl. Acad. Sci. USA, 106, 20610-20615, 2009.

Marengo, J. A., Chou, S. C., Kay, G., Alves, L. M., Pesquero, J. F., Soares, W. R., Santos, D. C., Lyra, A. A., Sueiro, G., Betts, R., Chagas, D. J., Gomes, J. L., Bustamante, J. F., and Tavares, P.: Development of regional future climate change scenarios in South America using the Eta CPTEC/HadCM3 climate change projections: climatology and regional analyses for the Amazon, So Francisco and the Parana River basins, Clim. Dynam., 38, 1829-1848, 2012.

Marengo, J. A., Tomasella, J., Alves, L. M., Soares, W. R., and Rodriguez, D. A.: The drought of 2010 in the context of historical droughts in the Amazon region, Geophys. Res. Lett., 38, L12703, doi:10.1029/2011GL047436, 2011. 
McMurtrie, R. E., Leuning, R., Thompson, W. A., and Wheeler, A. M.: A Model of Canopy Photosynthesis and Water-Use Incorporating a Mechanistic Formulation of Leaf Co2 Exchange, Forest Ecol. Manage., 52, 261-278, 1992.

Medlyn, B. E., Duursma, R. A., Eamus, D., Ellsworth, D. S., Prentice, I. C., Barton, C. V. M., Crous, K. Y., de Angelis, P., Freeman, M., and Wingate, L.: Reconciling the optimal and empirical approaches to modelling stomatal conductance, Global Change Biol., 17, 2134-2144, 2011.

Medlyn, B. E., Duursma, R. A., De Kauwe, M. G., and Prentice, I. C.: The optimal stomatal response to atmospheric $\mathrm{CO} 2$ concentration: Alternative solutions, alternative interpretations, Agr. Forest Meteorol., 182, 200-203, 2013.

Medvigy, D., Wofsy, S. C., Munger, J. W., Hollinger, D. Y., and Moorcroft, P. R.: Mechanistic scaling of ecosystem function and dynamics in space and time: Ecosystem Demography model version 2, J. Geophys. Res., 114, G01002, doi:10.1029/2008JG000812, 2009a.

Meir, P. and Woodward, F. I.: Amazonian rain forests and drought: response and vulnerability, New Phytol., 187, 553-557, 2010.

Meir, P., Metcalfe, D. B., Costa, A. C., and Fisher, R. A.: The fate of assimilated carbon during drought: impacts on respiration in Amazon rainforests, Philos. Trans. Roy. Soc. Lon. Ser. B, 363, 1849-1855, 2008.

Meir, P., Mencuccini, M., and Dewer, R. C.: Tree mortality during drought: narrowing the gaps in understanding and prediction, New Phytol., doi:10.1111/nph.13382, online first, 2015.

Mercado, L., Lloyd, J., Carswell, F., Malhi, Y., Meir, P., and Nobre, A. D.: Modelling Amazonian forest eddy covariance data: a comparison of big leaf versus sun/shade models for the C-14 tower at Manaus I. Canopy photosynthesis, Acta Amazonica, 36, 69-82, 2006.

Mercado, L. M., Lloyd, J., Dolman, A. J., Sitch, S., and Patiño, S.: Modelling basin-wide variations in Amazon forest productivity - Part 1: Model calibration, evaluation and upscaling functions for canopy photosynthesis, Biogeosciences, 6, 1247-1272, doi:10.5194/bg-6-1247-2009, 2009.

Moorcroft, P. R., Hurtt, G. C., and Pacala, S. W.: A method for scaling vegetation dynamics: The ecosystem demography model (ED), Ecol. Monogr., 71, 557-585, 2001.

Nepstad, D. C., Moutinho, P., Dias, M. B., Davidson, E., Cardinot, G., Markewitz, D., Figueiredo, R., Vianna, N., Chambers, J., Ray, D., Guerreiros, J. B., Lefebvre, P., Sternberg, L., Moreira, M., Barros, L., Ishida, F. Y., Tohlver, I., Belk, E., Kalif, K., and Schwalbe, K.: The effects of partial throughfall exclusion on canopy processes, aboveground production, and biogeochemistry of an Amazon forest, J. Geophys. Res.-Atmos., 107, 8085, doi:10.1029/2001JD000360, 2002.

Oleson, K. W., Dai, Y., Bonan, G. B., Bosilovich, M., Dirmeyer, P., Hoffman, F., Levis, S., Niu, G. Y., Thornton, P. E., Vertenstein, M., Yang, Z. L., and Zeng, X.: Technical description of the Community Land Model (CLM), NCAR Technical Note, 2004.

Oleson, K. W., Niu, G. Y., Yang, Z. L., Lawrence, D. M., Thornton, P. E., Lawrence, P. J., Stockli, R., Dickinson, R. E., Bonan, G. B., Levis, S., Dai, A., and Qian, T.: Improvements to the Community Land Model and their impact on the hydrological cycle, J. Geophys. Res.-Biogeo., 113, G01021, doi:10.1029/2007JG000563, 2008.
Powell, T. L., Galbraith, D. R., Christoffersen, B. O., Harper, A., Imbuzeiro, H. M., Rowland, L., Almeida, S., Brando, P. M., da Costa, A. C., Costa, M. H., Levine, N. M., Malhi, Y., Saleska, S. R., Sotta, E., Williams, M., Meir, P., and Moorcroft, P. R.: Confronting model predictions of carbon fluxes with measurements of Amazon forests subjected to experimental drought, New Phytol., 200, 350-365, doi:10.1111/nph.12390, 2013.

Reed, S. C., Wood, T. E., and Cavaleri, M. A.: Tropical forests in a warming world, New Phytol., 193, 27-29, 2012.

Reichstein, M., Bahn, M., Ciais, P., Frank, D., Mahecha, M. D., Seneviratne, S. I., Zscheischler, J., Beer, C., Buchmann, N., Frank, D. C., Papale, D., Rammig, A., Smith, P., Thonicke, K., van der Velde, M., Vicca, S., Walz, A., Wattenbach, M.: Climate extremes and the carbon cycle, Nature, 500, 287-295, doi:10.1038/Nature12350, 2013.

Sellers, P. J.: Canopy Reflectance, Photosynthesis and Transpiration, Int. J. Remote. Sens., 6, 1335-1372, 1985.

Sellers, P. J., Berry, J. A., Collatz, G. J., Field, C. B., and Hall, F. G.: Canopy Reflectance, Photosynthesis, and Transpiration .3. A Reanalysis Using Improved Leaf Models and a New Canopy Integration Scheme, Remote Sens. Environ., 42, 187-216, 1992.

Sellers, P. J., Randall, D. A., Collatz, G. J., Berry, J. A., Field, C. B., Dazlich, D. A., Zhang, C., Collelo, G. D., and Bounoua, L.: A revised land surface parameterization $(\mathrm{SiB} 2)$ for atmospheric GCMs .1. Model formulation, J. Climate, 9, 676-705, 1996.

Sitch, S., Huntingford, C., Gedney, N., Levy, P. E., Lomas, M., Piao, S. L., Betts, R., Ciais, P., Cox, P., Friedlingstein, P., Jones, C. D., Prentice, I. C., and Woodward, F. I.: Evaluation of the terrestrial carbon cycle, future plant geography and climate-carbon cycle feedbacks using five Dynamic Global Vegetation Models (DGVMs), Global Change Biol., 14, 2015-2039, 2008.

Tribuzy, E. S.: Variações da temperatura foliar do dossel e o seu efeito na taxa assimilatória de $\mathrm{CO} 2$ na Amazônia Central, $\mathrm{PhD}$, Universidade de São Paulo, São Paulo, 2005.

Williams, M.: A three-dimensional model of forest development and competition, Ecol. Model., 89, 73-98, 1996.

Williams, M., Schwarz, P. A., Law, B. E., Irvine, J., and Kurpius, M. R.: An improved analysis of forest carbon dynamics using data assimilation, Global Change Biol., 11, 89-105, 2005.

Wood, T. E., Cavaleri, M. A., and Reed, S. C.: Tropical forest carbon balance in a warmer world: a critical review spanning microbialto ecosystem-scale processes, Biol. Rev. Camb. Philos. Soc., 87, 912-927, 2012.

Zhou, S. X., Duursma, R. A., Medlyn, B. E., Kelly, J. W. G., and Prentice, I. C.: How should we model plant responses to drought? An analysis of stomatal and non-stomatal responses to water stress, Agr. Forest Meteorol., 182, 204-214, 2013.

Zhou, X. H., Weng, E. S., and Luo, Y. Q.: Modeling patterns of nonlinearity in ecosystem responses to temperature, $\mathrm{CO} 2$, and precipitation changes, Ecol. Appl., 18, 453-466, 2008. 